\title{
Calcium channel-dependent induction of long-term synaptic plasticity at excitatory Golgi cell synapses of cerebellum
}

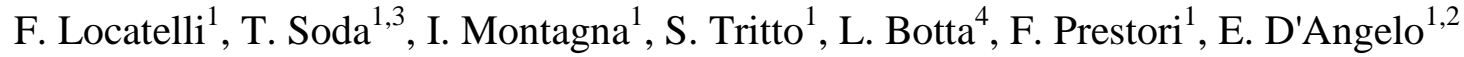 \\ ${ }^{1}$ Department of Brain and Behavioral Sciences, University of Pavia, Pavia, Italy \\ ${ }^{2}$ Brain Connectivity Center, IRCCS Mondino Foundation, Pavia, Italy \\ ${ }^{3}$ Museo Storico della Fisica e Centro Studi e Ricerche Enrico Fermi, Rome, Italy \\ ${ }^{4}$ Department of Biology and Biotechnology "L. Spallanzani", University of Pavia, Pavia, Italy
}

Correspondence should be addressed to:

Prof. Egidio D'Angelo

University of Pavia

Dept of Brain and Behavioral Sciences

via Forlanini 6, 27100 Pavia, Italy

dangelo@unipv.it

Number of pages:

Number of tables:

Number of figures:

Number of words: -Abstract, -Introduction, -Discussion

Running Title: Golgi cell bidirectional plasticity

Key words: cerebellum, Golgi cell, synaptic plasticity, $\mathrm{Ca}^{2+}$ channels

Acknowledgments. This project has received funding from: the Human Brain Project (European Union's Horizon 2020 Framework Program for Research and Innovation) under Grant Agreement No. 720270 (SGA1) and No. 785907 (SGA2) to ED; Centro Fermi grant MNL to ED. TS was supported by MNL, ST and FL by Human Brain Project. Special thanks to Javier DeFelipe 
(Department of Neuroanatomy and Cell Biology, Instituto Cajal (CSIC), Madrid, Spain) for Golgi cell morphological reconstruction.

Author contribution. FL performed the bulk of electrophysiological experiments and data analysis, TS performed part of the electrophysiological experiments, ST performed microscopy cell reconstruction, LB performed mice genotyping, FP performed part of the data analysis and wrote the paper, ED coordinated the work and wrote the paper.

\begin{abstract}
The Golgi cells, together with granule cells and mossy fibers, form a neuronal microcircuit regulating information transfer at the cerebellum input stage. Despite theoretical predictions, little was known about long-term synaptic plasticity at Golgi cell synapses. Here we have used wholecell patch-clamp recordings and calcium imaging to investigate long-term synaptic plasticity at excitatory synapses impinging on Golgi cells. In acute mouse cerebellar slices, mossy fiber thetaburst stimulation (TBS) could induce either long-term potentiation (LTP) or long-term depression (LTD) at mossy fiber-Golgi cell and granule cell-Golgi cell synapses. This synaptic plasticity showed a peculiar voltage-dependence, with LTD or LTP being favored when TBS induction occurred at depolarized or hyperpolarized potentials, respectively. LTP required, in addition to NMDA channels, activation of T-type $\mathrm{Ca}^{2+}$ channels, while LTD required uniquely activation of Ltype $\mathrm{Ca}^{2+}$ channels. Notably, the voltage-dependence of plasticity at the mossy fiber-Golgi cell synapses was inverted with respect to pure NMDA receptor-dependent plasticity at the neighboring mossy fiber-granule cell synapse, implying that the mossy fiber presynaptic terminal can activate different induction mechanisms depending on the target cell. In aggregate, this result shows that Golgi cells show cell-specific forms of long-term plasticity at their excitatory synapses, that could play a crucial role in sculpting the response patterns of the cerebellar granular layer.
\end{abstract}

\title{
Significance statement
}

This paper shows for the first time a novel form of $\mathrm{Ca}^{2+}$ channel-dependent synaptic plasticity at the excitatory synapses impinging on cerebellar Golgi cells. This plasticity is bidirectional and inverted with respect to NMDA receptor-dependent paradigms, with LTD and LTP being favored at depolarized and hyperpolarized potentials, respectively. Furthermore, LTP and LTD induction requires differential involvement of T-ype and L-type voltage-gated $\mathrm{Ca}^{2+}$ channels rather than the 
NMDA receptors alone. These results, along with recent computational predictions, support the idea that Golgi cell plasticity could play a crucial role in controlling information flow through the granular layer along with cerebellar learning and memory.

\section{Introduction}

Several forms of plasticity are thought to provide the substrate for learning and memory in brain microcircuits (Bliss et al., 2014; Volianskis et al., 2015). In the cerebellum, which is involved in motor learning and cognitive processing (Marr, 1969; Ito, 2008; Koziol et al., 2014; Sokolov et al., 2017; D'Angelo, 2019), more than 15 diverse forms of long-term synaptic and non-synaptic plasticity have been reported at several sites across the granular layer, molecular layer and deep cerebellar nuclei (Hansel et al., 2001; Gao et al., 2012; D'Angelo et al., 2016). In the granular layer, non-synaptic plasticity has been shown both in granule cells (Armano et al., 2000) and Golgi cells (Hull et al., 2013), while long-term synaptic plasticity has been reported at the synapses made by mossy fibers with granule cells (Armano et al., 2000; Medina and Mauk, 2000; Zhang and Linden, 2006; D'Errico et al., 2009; Pugh and Raman, 2009; D'Angelo, 2014; Sgritta et al., 2017; Moscato et al., 2019). However, long-term synaptic plasticity elicited by mossy fiber stimulation in Golgi cells has not been investigated yet.

Golgi cells are the main inhibitory interneurons of the granular layer, where they receive excitatory inputs from mossy fibers and granule cells (Palay, 1974). The mossy fibers make synapses on Golgi cell basolateral dendrites inside the cerebellar glomeruli, which also contact the dendrites of granule cells. The granule cells, in turn, make synapses both on the Golgi cell basolateral dendrites through their ascending axons and on the apical dendrites through the parallel fibers. All these excitatory synapses are glutamatergic and express AMPA and NMDA receptors activated during synaptic transmission (Misra et al., 2000; Cesana et al., 2013). Golgi cells also receive inhibitory innervation from neighboring Golgi cells and other inhibitory interneurons (Dieudonne, 1998; Bureau et al., 2000; Misra et al., 2000; Hull and Regehr, 2012). Finally, Golgi cell axons contact granule cell dendrites inside the glomeruli, thus regulating information flow to the cerebellar cortex trough a mix of feedback and feed forward inhibition (D'Angelo, 2008; Kanichay and Silver, 2008; Cesana et al., 2013; D'Angelo et al., 2013). It has been suggested that Golgi cells dynamically control the gain and the temporal pattern of granule cell discharge in response to mossy fiber activity (Marr, 1969; Mitchell and Silver, 2003; D'Angelo and De Zeeuw, 2009; Billings et al., 2014) and this essential role has been supported by their acute ablation, which causes severe motor deficits and ataxia (Watanabe et al., 1998). 
Golgi cells are low-frequency pacemakers (Dieudonne, 1998; Forti et al., 2006) and they have recently been shown to express $\mathrm{Ca}^{2+}$ channels in the dendrites (Rudolph et al., 2015). The $\mathrm{Ca}^{2+}$ channels, along with postsynaptic NMDA receptors, may actually enable the induction of long-term synaptic plasticity, as observed at other synapses (Lisman, 1989; Shouval et al., 2002; Volianskis et al., 2015; Leresche and Lambert, 2017). In this work we have combined patch-clamp recordings and calcium imaging techniques to show, for the first time, the existence of bidirectional long-term plasticity at the excitatory Golgi cell synapses activated by patterned mossy fiber stimulation. These results support recent computational predictions about the critical role that such forms of plasticity would play in controlling learning and computation in the cerebellar granular layer (Schweighofer et al., 2001; Garrido et al., 2013; Garrido et al., 2016).

\section{Methods}

The experiments have been performed on 16-to 21-day-old ( $\mathrm{P} 0=$ day of birth) GlyT2-GFP mice (of either sex) heterozygous for the bacterial artificial chromosome insertion of EGFP under the glycine transporter type 2 gene (Zeilhofer et al., 2005). All procedures were conducted in accordance with European guidelines for the care and use of laboratory animals (Council Directive 2010/63/EU), and approved by the ethical committee of Italian Ministry of Health (628/2017-PR).

The mice were anesthetized with halothane (Sigma-Aldrich) and killed by decapitation in order to remove the cerebellum for acute slice preparation according to established techniques (Forti et al., 2006; Cesana et al., 2013).

\section{Slices preparation and solutions}

The cerebellar vermis was isolated and fixed on the vibroslicer's stage (Leica VT1200S; Leica Biosystems) with cyano-acrylic glue. Acute $220 \mu \mathrm{m}$-thick slices were cut in the parasagittal plane and immersed in ice-cold $\left(2-3^{\circ} \mathrm{C}\right)$ solution containing (in $\left.\mathrm{mM}\right)$ : potassium gluconate $130, \mathrm{KCl} 15$, ethylene glycol-bis ( $\beta$-aminoethyl ether) N,N,N',N'-tetraacetic acid (EGTA) 0.2, N-2-hydroxyethyl piperazine-N-2-ethanesulphonic acid (Hepes) 20, glucose 10, pH 7.4 with $\mathrm{NaOH}$ (Dugué et al., 2005). Slices were incubated for at least $1 \mathrm{~h}$ before recordings in oxygenated bicarbonate-buffered (Kreb's solution) saline maintained at $32^{\circ} \mathrm{C}$, containing (in $\mathrm{mM}$ ): $\mathrm{NaCl} 120, \mathrm{KCl} 2, \mathrm{MgSO}_{4} 1.2$, $\mathrm{NaHCO}_{3} 26, \mathrm{KH}_{2} \mathrm{PO}_{4} 1.2, \mathrm{CaCl}_{2}$ 2, glucose 11 (pH 7.4 when equilibrated with $95 \% \mathrm{O}_{2}-5 \% \mathrm{CO}_{2}$ ). During recordings, slices were placed in a chamber continuously perfused at a rate of $1.5 \mathrm{ml} / \mathrm{min}$ with oxygenated Kreb's solution and maintained at $32^{\circ} \mathrm{C}$ with a Peltier feedback device (TC-324B, Warner Instrument Corp.). SR 95531 (gabazine) and strychnine were routinely added to the bath solution to block GABAergic and glycinergic inhibition, respectively. 


\section{Electrophysiological recordings}

Slices were visualized under an upright epifluorescence microscope (Axioskop 2 FS; Carl Zeiss) equipped with a 63, 0.9 NA water-immersion objective (Olympus). Whole-cell patch-clamp was performed from the soma of Golgi cells Patch pipettes were pulled from borosilicate glass capillaries (Sutter Instruments) and filled with an intracellular solution containing (in $\mathrm{mM}$ ): potassium gluconate 145, $\mathrm{KCl}$ 5, HEPES 10, EGTA 0.2, $\mathrm{MgCl}_{2}$ 4.6, ATP-Na 4 , GTP-Na 0.4 , adjusted at $\mathrm{pH} 7.3$ with $\mathrm{KOH}$. In a different series of recordings, EGTA was increased to $10 \mathrm{mM}$. Pipettes had a resistance of 3-5 M $\Omega$ when immersed in the bath. For experiments combining current-clamp and fluorescence $\mathrm{Ca}^{2+}$ imaging, the pipette solution was the following (in $\mathrm{mM}$ ): potassium gluconate 145, $\mathrm{KCl}$ 5, HEPES 10, $\mathrm{MgCl}_{2}$ 4.6, ATP-Na $\mathrm{Na}_{2}$, GTP-Na 0.4 and 0.2 Oregon Green BAPTA-1 (OG1), pH adjusted at 7.3 with $\mathrm{KOH}$. In a set of experiments, EGTA (0.2 mM) was substituted with BAPTA $(0.2 \mathrm{mM})$.

Cell current and voltage were recorded with Multiclamp 700B, sampled with Digidata 1550 interface, and analyzed off-line with pClamp10 software (Molecular Devices). In voltage-clamp, the recorded currents were low-pass filtered at $\mathrm{fc}=10 \mathrm{kHz}(-3 \mathrm{~dB})$ and digitized at $50 \mathrm{kHz}$. According to (Forti et al., 2006) recordings were discarded when the basal current at $-70 \mathrm{mV}$ was negative to 150 pA. Series resistance $\left(\mathrm{R}_{\mathrm{s}}\right)$ was $8.3 \pm 0.5 \mathrm{M} \Omega$, $(\mathrm{n}=99)$, was constantly monitored during recordings and compensated by $40-80 \%$. Recordings were accepted when $\mathrm{R}_{\mathrm{s}}$ showed variations $<=$ $\pm 20 \%$.

To elicit Golgi cell EPSCs the mossy fiber bundle was stimulated using a large-bore patch pipette connected to a stimulus isolation unit and filled with Kreb's solution. Individual stimuli were $200 \mu \mathrm{s}$ monopolar square pulses. The stimulation pipette was positioned in the white matter in an appropriate position to evoke monosynaptic mossy fiber inputs along with dysynaptic granule cell inputs according to (Cesana et al., 2013) (Fig.1A).

\section{Post hoc visualization of AlexaFluo594-filled Golgi cells}

After recordings, cerebellar slices were fixed at $4{ }^{\circ} \mathrm{C}$ for at least $24 \mathrm{~h}$ in phosphate buffer saline (PBS) containing 4\% paraformaldeyde (PAF), thoroughly washed in PBS and mounted in Fluoroshield Mounting Medium with DAPI (Abcam). Images were captured using a LEICA TCS SP5 confocal microscope (Centro Grandi Strumenti, UNIPV). Z-stack images were acquired for Golgi cell visualization and morphological reconstruction with the Neurolucida System (MBF Bioscience). 


\section{Calcium imaging}

Calcium imaging was performed as reported previously (Gall et al., 2005; D'Errico et al., 2009; Sgritta et al., 2017) by using Oregon green BAPTA-1 (OG1, Molecular Probes). Briefly, $200 \mu \mathrm{M}$ OG1 was added to the intracellular solution as a substitution for the EGTA buffer. Golgi cells were identified with a $\times 63,0.9$ NA water immersion objective. Digital fluorescence images were obtained using an excitation light source from T.I.L.L. Photonics (Planegg) controlled through Axon Imaging Workbench AIW5.2 (INDEC Systems). Images were acquired with a $50 \mathrm{~ms}$ exposure/image at video rate. Acquisition started after allowing $>2 \mathrm{~min}$ for dye loading in the neuron. After this time, the resting fluorescence $\left(\mathrm{F}_{0}\right)$ varied by less than $5 \%$ in each analyzed cell region for the entire recording time and the background fluorescence $\left(\mathrm{B}_{0}\right)$ was also stationary. All stimulation protocols were separated by a minimum of $60 \mathrm{~s}$ in order to allow $\left[\mathrm{Ca}^{2+}\right]_{\mathrm{i}}$ to return to basal level. Cell damage was identified by the following signs: the failure of $200 \mathrm{~ms}$ depolarization at $0 \mathrm{mV}$ in voltage clamp to elicit a fluorescence transient or the sudden inability of fluorescence levels to recover to baseline after stimulation. We never observed bleaching of OG1 basal fluorescence during individual stimulations. Stimulus-induced fluorescence changes were analyzed off-line in the regions of interest (ROIs). For each experiment, regions were drawn by eye defining the ROIs in the first image of a sequence, thus giving a set of two-dimensional arrays of pixels. In addition, background fluorescence was evaluated by defining a background area of similar size close to the cell. For each ROI, a measurement of the relative change in fluorescence during cell stimulation, $\Delta \mathrm{F} / \mathrm{F}_{0}\left(\mathrm{~F}_{0}\right.$ is the mean resting fluorescence), was obtained as follows. (a) For each consecutive $\mathrm{n}^{\text {th }}$ image in the sequence, the fluorescence intensity $\mathrm{f}_{(\mathrm{n})}$ was evaluated in the ROI. (b) Background fluorescence was measured simultaneously in the background area, $\mathrm{B}_{(\mathrm{n})}$. Care was taken to check that background fluorescence was stationary. (c) The background-subtracted fluorescence $F_{(n)}=f_{(n)}-B_{(n)}$ was then used to evaluate $\Delta F / F_{0(n)}=\left(F_{(n)}-F_{0}\right) / F_{0}$, where $F_{0}$ is the average background-subtracted resting fluorescence over four consecutive images before applying the stimulus. This background subtraction procedure was used to account for slice autofluorescence and/or fluorescence arising from outflow of dye from the pipette prior to seal formation. ROIs for analysis of somatic signals were chosen near the visible soma border to minimize the unfavourable surface/volume ratio for estimation of near-membrane $\mathrm{Ca}^{2+}$ changes. Analysis of images was performed with AIW-5.2 software.

\section{Drug application}

Strychnine hydrochloride $(1 \mu \mathrm{M})$ was obtained from Sigma-Aldrich. All other drugs were from Abcam: D-2-amino-5-phosphonovalerate (D-APV, $50 \mu \mathrm{M}$ ), (S)- $\alpha$-Methyl-4-carboxyphenylglycine 
(S-MCPG, $500 \mu \mathrm{M})$, mibefradil dihydrochloride $(10 \mu \mathrm{M})$, nifedipine $(20 \mu \mathrm{M})$ and 6-imino-3-(4methoxyphenyl)-1(6H)-pyridazinebutanoic acid hydrobromide (SR95531, gabazine, $10 \mu \mathrm{M}$ ). Stock solutions were prepared in water and stored at $-20^{\circ} \mathrm{C}$. During experiments, aliquots were diluted in Kreb's solution and bath-applied.

\section{EPSC and TBS analysis}

Post-synaptic currents (EPSCs) elicited at $0.1 \mathrm{~Hz}$ (test frequency) were averaged and digitally filtered at $1.5 \mathrm{kHz}$ off-line. EPSC amplitude was measured as the difference between EPSC peak and baseline. After evoking EPSCs at $-70 \mathrm{mV}$ at the test frequency for 10-15 min (control period), the recording was switched to current clamp. Synaptic plasticity was induced by a theta-burst stimulation (TBS; eight $100 \mathrm{~ms}, 100 \mathrm{~Hz}$ bursts of impulses repeated every $250 \mathrm{~ms}$ ) from an average membrane potential $\left(\mathrm{V}_{\text {hold }}\right)$ around either $-55 \mathrm{mV}$ or $-40 \mathrm{mV}$ for LTP and LTD induction, respectively (Table 1).

\begin{tabular}{|c|c|c|}
\hline & $\begin{array}{c}\text { LTP } \\
\text { V hold (mV) }\end{array}$ & $\begin{array}{c}\text { LTD } \\
\text { V hold (mV) }\end{array}$ \\
\hline Control & $-57.2 \pm 1.1(n=6)$ & $-41.2 \pm 3.4(n=7)$ \\
\hline EGTA & $-59.3 \pm 0.8(n=5)$ & $-43.2 \pm 1.0(n=5)$ \\
\hline APV & $-54.6 \pm 1.4(n=5)$ & $-40.5 \pm 2.0(n=7)$ \\
\hline BAPTA & $-59.1 \pm 3.0(n=6)$ & $-45.9 \pm 1.5(n=6)$ \\
\hline $\mathrm{Ca}^{2+}$-imaging & $-60.7 \pm 1.6(n=8)$ & $-45.8 \pm 1.1(n=7)$ \\
\hline Nifedipine & & $-43.5 \pm 1.1(n=5)$ \\
\hline Mibefradil & $-58.2 \pm 0.9(n=6)$ & \\
\hline
\end{tabular}

LTP and LTD $V_{\text {hold }}$ were not significantly different between different conditions. One-way ANOVA: $F_{\text {LTP }}(5,31)=1.58, p=0.19 ; F_{\text {LTD }}(5,31)=1.55, p=0.2$

After delivering the TBS, voltage-clamp at $-70 \mathrm{mV}$ was reestablished and stimulation was restarted at the test frequency. The efficiency of Golgi cell synaptic excitation during TBS was expressed as mean burst depolarization $\left(\mathrm{V}_{\text {mean }}\right)$ and spike frequency $\left(\mathrm{f}_{\mathrm{TBS}}\right)$. $\mathrm{V}_{\text {mean }}$ was estimated as the mean of average values measured in the $100 \mathrm{msec}$ of each burst (tracings were filtered at $100 \mathrm{~Hz}$ ). $\mathrm{V}_{\text {jump }}$ was measured as the difference between $V_{\text {hold }}$ and $V_{\text {mean }}$ (see Fig.2). Long-term synaptic changes were 
measured after $30 \mathrm{~min}$. In order to study the latency distributions of evoked EPSCs (see Fig. 1), synaptic currents were detected in the $15 \mathrm{~ms}$ window after a stimulus using a threshold-abovebaseline detector (MiniAnalysis program; Synaptosoft Inc, Fort Lee, NJ), and their latency from stimulus onset was measured. Fittings for the latency histograms were made by using nonlinear curve fit (Gauss) (OriginPro 8). To demonstrate the presence of an evoked dysynaptic response, the probability that spontaneous EPSCs (sEPSCs) occured by chance in the time window between 2.5 and $15 \mathrm{~ms}$ after the stimulus (see Fig. 1C) was calculated by Poisson distribution (Forti et al., 2006)

$$
p(x)=\frac{\mu^{x} \cdot e^{-\mu}}{x !}
$$

where $\mu$ is the average number of sEPSC per interval and $x$ is the number of times an sEPSC occurs in the same interval, where $\mu$ is $\mathrm{f}_{\mathrm{SEPSC}} \cdot 0.0125 \mathrm{sec}$ [the frequency of $\mathrm{sEPSCS}$ is $\mathrm{f}_{\mathrm{sEPSC}}=2.98 \pm 0.25 \mathrm{~Hz}$ $, \mathrm{n}=99)$ ] In histograms shown in Fig.1, the probability of having one sEPSCs per trial was therefore $p(1)=0.036, p(2)=7 \times 10^{-4}, \quad p(3)=8 \times 10^{-6}, p(4)=8 \times 10^{-8}$, ruling out the de facto the potential contribution of sEPSCs.

\section{Statistical procedures}

All data are reported as mean \pm MSE. The normality of data was checked by applying the ShapiroWilk's test. Means were compared by a Student's $t$-test or by one-way parametric analysis of variance (ANOVA). Where appropriate, data were further assessed by conducting the Tukey post hoc test. The analysis was two-sided, with level of significance $\alpha=0.05$. All statistical analyses were done using OriginPro 8.

\section{Results}

Whole-cell patch-clamp recordings were performed from Golgi cells in acute cerebellar slices of GlyT2-GFP mice (P16-P21). Golgi cells were identified as GFP fluorescent neurons in the granular layer showing a large soma (>10 $\mu \mathrm{m}$ diameter) and typical single-spike rhythmic firing (1$10 \mathrm{~Hz}$; Fig.1B) (Forti et al., 2006; Cesana et al., 2013) from an average membrane potential $\mathrm{V}_{\mathrm{m}}=-$ $49.8 \pm 0.8 \mathrm{mV}$ ( $\mathrm{n}=99$ ). It should also be considered that, in addition to Golgi cells, GFP is expressed in other types of GABAergic interneurons of the granular layer of GlyT2-GFP mice, namely Lugaro cells and globular cells (Zeilhofer et al., 2005; Simat et al., 2007), which cannot be easily identified in acute slices due to the high density and extensive overlap among the numerous GFP-containing axonal and dendritic processes. In a subset of cells $(n=8)$, we obtained post hoc morphological 
confirmation by filling interneurons with $50 \mu \mathrm{M}$ AlexaFluo 594 and carrying out laser confocal microscopy reconstructions (Fig.1B). Golgi cells showed a soma diameter of $17 \pm 0.833 \mu \mathrm{m}(\mathrm{n}=8)$ with several basolateral dendrites remaining in the granular layer $(30.85 \pm 6.15 \mu \mathrm{m}$ long; $\mathrm{n}=8)$ and apical dendrites $(70.14 \pm 9.73 \mu \mathrm{m}$ long; $\mathrm{n}=8)$ ascending towards the molecular layer. Their axons diffusely extended in the granular layer (Dieudonne, 1998; Misra et al., 2000).

\section{EPSCs evoked in Golgi cells by mossy fiber stimulation}

In order to investigate the contributions of mossy fiber and granule cell synaptic inputs to Golgi cell excitation, EPSCs were recorded at $-70 \mathrm{mV}$ in the presence of gabazine $(10 \mu \mathrm{M})$ and strychnine $(1 \mu \mathrm{M})$ to block GABAergic and glycinergic synapses, respectively (Dumoulin et al., 2001; Hull and Regehr, 2012; Cesana et al., 2013). Golgi cells EPSCs were activated by mossy fiber stimulation at least $300 \mu \mathrm{m}$ away from soma to avoid direct activation of granule cell axons (Cesana et al., 2013). This configuration recruited monosynaptic mossy fiber inputs and disynaptic mossy fiber - granule cell inputs (Fig. 1A,C). Mossy fiber stimulation, adjusted to obtain 50-250 pA responses, evoked in a group of Golgi cells (18 out of 99) an isolated EPSC with short latency (Fig. 1C), with latency histograms showing a single narrow peak at $2.10 \pm 0.13 \mathrm{~ms}(\mathrm{n}=18)$. In the remaining cells (81 out of 99), stimulation evoked multiple EPSCs and gave rise to multiple components in the average trace (Fig. 1C). A Poisson distribution generated with the mean sEPSC frequency ruled out that these late events were actually sEPSCs (see Methods). The latency histograms of multimodal distributions showed a first narrow peak at $2.05 \pm 0.05 \mathrm{~ms}(\mathrm{n}=81)$, followed by late humps [peaking at $4.64 \pm 0.19 \mathrm{~ms}(\mathrm{n}=33), 6.65 \pm 0.27 \mathrm{~ms}(\mathrm{n}=40), 10.45 \pm 0.89$ $(\mathrm{n}=7)$, respectively]. The multiple peaks were separated by $2.30 \pm 0.13 \mathrm{~ms}(\mathrm{n}=67), 2.65 \pm 0.29 \mathrm{~ms}$ $(\mathrm{n}=33)$ and $3.55 \pm 0.76 \mathrm{~ms}(\mathrm{n}=7)$, respectively. In aggregate, synaptic responses could be separated into monosynaptic EPSCs (m-EPSCs) and disynaptic EPSCs (d-EPSCs). According to a previous detailed analysis (Cesana et al., 2013), the m-EPSCs are likely to arise at the mossy fiber - Golgi cell synapse (Fig. 1A, connection 1), whereas d-EPSC are likely to originate from mossy fiber granule cell - Golgi cell disynaptic inputs on the ascending axon (Fig. 1B, connection 2) as well as from short and long mossy fiber - FGFgranule cell - Golgi cell disynaptic inputs on the parallel fibers (Fig. 1B, connection 3 and 4). 


\section{Voltage-dependent plasticity at mf-Golgi cell synapses}

The presence of long-term synaptic plasticity between mossy fibers and Golgi cells was investigated in the presence of $\mathrm{GABA}_{\mathrm{A}}$ and glycine receptor blockade by $10 \mu \mathrm{M}$ gabazine and 1 $\mu \mathrm{M}$ strychnine, respectively (Fig.2). Following a 10-min control period to monitor recording stability, mossy fibers were stimulated with high-frequency impulse trains in current-clamp reproducing a TBS patterns (See Methods), which is known to induce persistent neurotransmission changes at the neighboring synapses made by mossy fibers with granule cells (D'Angelo et al., 1999; Hansel et al., 2001; D'Errico et al., 2009; Andreescu et al., 2011). At the mossy fiber granule cell synapse, membrane potential before TBS ( $\left.\mathrm{V}_{\text {hold }}\right)$ is an important determinant of the sign of synaptic plasticity, with LTP arising from depolarized and LTD from hyperpolarized potentials. Here too, TBS was delivered from different levels of $\mathrm{V}_{\text {hold }}$ (depolarized and hyperpolarized, $\mathrm{TBS}_{\mathrm{dep}}$ and TBS $_{\text {hyp}}$ ).

Quite unexpectedly, following TBS pairing at $\mathrm{V}_{\text {hold }}=-40.9 \pm 3.4 \mathrm{mV}(\mathrm{n}=7)$, both $\mathrm{m}$-EPSC and d-EPSC amplitude decreased by $-35.2 \pm 8.6 \%(\mathrm{n}=7$; Student's paired $t$ test, $\mathrm{p}=0.036)$ and -47.1 $\pm 12.82 \%(\mathrm{n}=6$; Student's paired $t$ test, $\mathrm{p}=0.048)$. Conversely, following TBS pairing at $\mathrm{V}_{\text {hold }}=-$ $57.2 \pm 1.2 \mathrm{mV}(\mathrm{n}=6$; this potential was significantly different from the other one; Student's unpaired $t$ test, $\mathrm{p}=0.002$ ), m-EPSC and d-EPSC amplitude increased by $46.2 \pm 7.2 \%$ ( $\mathrm{n}=6$; Student's paired $t$ test, $\mathrm{p}=0.007)$ and $30.6 \pm 8.2 \%(\mathrm{n}=6$; Student's paired $t$ test, $\mathrm{p}=0.049$; Fig.2A,B). Therefore, the relationship between membrane potential and plasticity was inverted in Golgi cells compared to granule cells (D'Angelo et al., 1999; D'Errico et al., 2009).

The $\mathrm{m}$-EPSC changes obtained at different $\mathrm{V}_{\text {hold }}$ showed a significant negative linear correlation $\left(\mathrm{R}^{2}=0.57\right.$; one-way ANOVA, $\left.\mathrm{p}=0.0018\right)$ with LTD and LTP occurring at the depolarized and hyperpolarized $\mathrm{V}_{\text {hold }}$, respectively (Fig. 2D). The m-EPSC changes also depended on the membrane depolarizing jump ( $\mathrm{V}_{\text {jump }}$ ) during TBS (Fig. 2C,E).

In recordings that showed LTP, TBS caused a strong Golgi cell excitation $\left(\mathrm{V}_{\text {jump }}=10.0 \pm\right.$ $1.9 \mathrm{mV}, \mathrm{n}=6$ ) characterized by a depolarizing hump sustaining a robust action potential discharge $\left(\mathrm{f}_{\mathrm{TBS}}=33.7 \pm 8.7 \mathrm{~Hz}, \mathrm{n}=6\right)$. Conversely, in the recordings that showed LTD, TBS was unable to generate a clear depolarizing hump $\left(\mathrm{V}_{\text {jump }}=-0.99 \pm 0.54 \mathrm{mV}, \mathrm{n}=7\right.$; Student's unpaired $t$ test, $\mathrm{p}=0.0016)$ but could still evoke an action potential discharge $\left(\mathrm{f}_{\mathrm{TBS}}=20.0 \pm 4.7 \mathrm{~Hz}, \mathrm{n}=7\right)$. Although the average action potential discharge frequency was higher in Golgi cells showing LTP than in those showing LTD, the difference was not statistically significant (Student's unpaired $t$ test, $\mathrm{p}=0.2$ ).

These results show an inverted voltage-dependent bidirectional plasticity at the mossy fiber Golgi cell synapses. 


\section{LTP and LTD require an elevation of postsynaptic $\mathrm{Ca}^{2+}$}

In a different series of recordings, in order to determine whether intracellular $\mathrm{Ca}^{2+}$ was required for LTP and LTD at mossy fiber-Golgi cell synapses, the pipette intracellular solution was supplemented with the calcium buffer, $10 \mathrm{mM}$ EGTA. After establishing the whole-cell configuration, we waited about 15 min to ensure adequate perfusion of EGTA into the dendritic compartment before applying LTP and LTD protocols. Figure 3 shows the time course of m-EPSC changes. The $10 \mathrm{mM}$ EGTA prevented both LTP (m-EPSC, $-4.2 \pm 4.4 \%, \mathrm{n}=5$; Student's paired $t$ test, $\mathrm{p}=0.53$; d-EPSC, $-7.5 \pm 6.0 \%, \mathrm{n}=7$; Student's paired $t$ test, $\mathrm{p}=0.35)$ and LTD (m-EPSC, 0.78 $\pm 6.8 \%$, $\mathrm{n}=5$; Student's paired $t$ test, $\mathrm{p}=0.8$; d-EPSC, $6.7 \pm 15.2 \%, \mathrm{n}=5$; Student's paired $t$ test, $\mathrm{p}=0.3$ ) (Fig. $3 \mathrm{~A}, \mathrm{~B})$. It should be noted that, compared to control, $\mathrm{TBS}_{\text {hyp }}(-59.3 \pm 0.8 \mathrm{mV}, \mathrm{n}=5$; Table 1) showed a weaker Golgi cell excitation $\left(\mathrm{V}_{\text {jump }}=4.4 \pm 1.1 \mathrm{mV}, \mathrm{n}=5\right.$; Student's unpaired $t$ test, $\left.\mathrm{p}=0.035\right)$ accompanied by reduced action potential discharge $\left(\mathrm{f}_{\mathrm{TBS}}=7.5 \pm 6.3 \mathrm{~Hz}, \mathrm{n}=5\right.$; Student's unpaired $t$ test, p=0.038; Fig. 3C), while $\mathrm{TBS}_{\text {dep }}(-43.2 \pm 1.0 \mathrm{mV}, \mathrm{n}=5$; Table 1) showed a stronger Golgi cell excitation $\left(\mathrm{V}_{\text {jump }}=3.8 \pm 1.6 \mathrm{mV}, \mathrm{n}=5\right.$; Student's unpaired $t$ test, $\left.\mathrm{p}=0.034\right)$ accompanied by a robust action potential discharge $\left(\mathrm{f}_{\mathrm{TBS}}=39.0 \pm 3.4 \mathrm{~Hz}, \mathrm{n}=5\right.$; Student's unpaired $t$ test, $\mathrm{p}=0.008$; Fig. 3C).

These results indicate that long-term plasticity at Golgi cell excitatory synapses requires postsynaptic calcium changes for induction, like other forms of LTP and LTD at central synapses (Artola et al., 1990; Artola and Singer, 1993; D'Angelo et al., 1999; Malenka and Bear, 2004; D'Errico et al., 2009; Sgritta et al., 2017).

\section{*** Fig. $3 * * *$}

\section{Voltage dependence of intracellular $\mathrm{Ca}^{2+}$ changes during induction}

The relationship between $\left[\mathrm{Ca}^{2+}\right]_{\mathrm{i}}$ changes and Golgi cell synaptic plasticity was investigated by $\mathrm{Ca}^{2+}$ imaging measurements using $200 \mu \mathrm{M}$ OG1 in the patch pipette (Gall et al., 2005; D'Errico et al., 2009; Sgritta et al., 2017). The $\left[\mathrm{Ca}^{2+}\right]_{\mathrm{i}}$ increase in the Golgi cell basolateral dendritic compartment (Fig. 4A,B) was significantly higher with $\mathrm{TBS}_{\text {hyp }}$ than $\mathrm{TBS}_{\text {dep }}\left[\left(\mathrm{F} / \mathrm{F}_{0}\right)_{\max }=0.23 \pm 0.02\right.$ vs $0.13 \pm 0.02, \mathrm{n}=6$ (13 dendrites); Student's paired $t$ test, $\left.\mathrm{p}=3.7 \mathrm{e}^{-6}\right]$. Since OG1 has a $\mathrm{Ca}^{2+}$ affinity similar to BAPTA, we performed control recordings with BAPTA in the intracellular pipette instead of EGTA allowing, therefore, a direct comparison of imaging with patch-clamp recordings. As

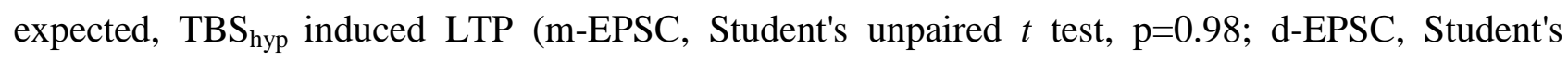
unpaired $t$ test, $\mathrm{p}=0.31$ ) and $\mathrm{TBS}_{\mathrm{dep}}$ induced LTD (m-EPSC, Student's unpaired $t$ test, $\mathrm{p}=0.45$; $\mathrm{d}$ - 
EPSC, Student's unpaired $t$ test, $\mathrm{p}=0.65$ ). These LTP and LTD were indistinguishable from those observed using $200 \mu \mathrm{M}$ EGTA (Fig. 4C, D). It should be noted that, during $\mathrm{TBS}_{\text {hyp }}$ and $\mathrm{TBS}_{\mathrm{dep}}$, Golgi cell excitation $\left(\mathrm{TBS}_{\mathrm{hyp}}\right.$, Student's unpaired $t$ test, $\mathrm{p}=0.12 ; \mathrm{TBS}_{\mathrm{dep}}$, Student's unpaired $t$ test, $\mathrm{p}=0.5)$ and action potential discharge $\left(\mathrm{TBS}_{\mathrm{hyp}}\right.$, Student's unpaired $t$ test, $\mathrm{p}=0.2 ; \mathrm{TBS}_{\mathrm{dep}}$, Student's unpaired $t$ test, $\mathrm{p}=0.54$ ) were not significantly different when using $200 \mu \mathrm{M}$ BAPTA instead of 200 $\mu \mathrm{M}$ EGTA (Fig. 4E).

$$
* * * \text { Fig. } 4 * * *
$$

\section{The role of NMDA receptors in LTP and LTD induction}

The classical mechanism by which membrane depolarization influences the induction of synaptic plasticity passes through the removal of voltage-dependent $\mathrm{Mg}^{2+}$ block from NMDA channels (Bliss et al., 2014) To examine whether NMDA receptors actually play a role in plasticity at the excitatory Golgi cell synapses, we delivered TBS in the presence of an NMDA receptor antagonist, D-APV. Bath application of D-APV $(50 \mu \mathrm{M})$ did not produce any remarkable changes in basal transmission (m-EPSC, $-3.3 \pm 3.1 \%, \mathrm{n}=13$; ,Student's paired $t$ test, $\mathrm{p}=0.16$ and d-EPSC, -9.7 $\pm 4.9 \%, \mathrm{n}=13$; Student's paired $t$ test, $\mathrm{p}=0.13$; Fig. 5A,B) but prevented the induction of LTP by $\mathrm{TBS}_{\text {hyp }}\left(\mathrm{V}_{\text {hold }}=-54.6 \pm 1.4 \mathrm{mV} ; \mathrm{n}=6\right.$; Table 1$)$. m-EPSC and d-EPSC amplitude changed by $-8.2 \pm$ $7.4 \%(\mathrm{n}=6$; Student's paired $t$ test, $\mathrm{p}=0.18)$ and $-3.0 \pm 20.0 \%(\mathrm{n}=7$; Student's paired $t$ test, $\mathrm{p}=0.7$; Fig. 5C, D), respectively. $\mathrm{TBS}_{\text {hyp }}$ showed a weaker Golgi cell excitation compared to control $\left(\mathrm{V}_{\text {jump }}\right.$ $=3.6 \pm 0.8 \mathrm{mV}, \mathrm{n}=6$; Student's unpaired $t$ test, $\mathrm{p}=0.018$ ) accompanied by a reduced action potential discharge $\left(\mathrm{f}_{\mathrm{TBS}}=2.5 \pm 1.6 \mathrm{~Hz}, \mathrm{n}=6\right.$; Student's unpaired $t$ test,p=0.015; Fig. 5E). Conversely, after $\mathrm{TBS}_{\text {dep }}\left(\mathrm{V}_{\text {hold }}=-40.2 \pm 1.7 \mathrm{mV} ; \mathrm{n}=7\right.$; Table 1$), \mathrm{m}$-EPSC and d-EPSC amplitude were reduced to $26.1 \pm 9.5 \%(\mathrm{n}=7 ;$ Student's paired $t$ test, $\mathrm{p}=0.037)$ and $19.4 \pm 6.7 \%(\mathrm{n}=7$; Student's paired $t$ test, $\mathrm{p}=0.05$; Fig. $5 \mathrm{C}, \mathrm{D})$, respectively. The magnitude of LTD in the presence of D-APV was not significantly different from control (Student's unpaired $t$ test, $\mathrm{p}=0.49$ ). Likewise, Golgi cell excitation (Student's unpaired $t$ test, $\mathrm{p}=0.7$ ) and action potential discharge during $\mathrm{TBS}_{\text {dep }}$ were not different from control (Student's unpaired $t$ test, $\mathrm{p}=0.73$ ) (Fig. 5E). These results indicate that NMDA receptor activation is required for LTP but not for LTD at Golgi cell excitatory synapses. 
The role of voltage-gated calcium channels in LTP and LTD induction

Since Golgi cell depolarization activates voltage-gated ionic channels, and since both LTP and LTD proved to depend on postsynaptic membrane voltage and $\mathrm{Ca}^{2+}$ concentration changes, we examined the role of voltage-gated calcium channels in the induction of LTD and LTP at mossy fiber-Golgi cell synapses. Actually both T-type (LVA) and L-type (HVA) $\mathrm{Ca}^{2+}$ channels have been reported along with their subcellular distribution (Solinas et al., 2007; Rudolph et al., 2015). T-type $\mathrm{Ca}^{2+}$ channels activate at membrane potentials positive to $-70 \mathrm{mV}$ and are fully inactivated beyond $40 \mathrm{mV}$, while L-type $\mathrm{Ca}^{2+}$ channels activate at membrane potentials positive to $-30 \mathrm{mV}$, suggesting a specific and differential engagement in LTP and LTD.

We first evaluated the effect of the LVA $\mathrm{Ca}^{2+}$ channel blocker, mibefradil, on LTP. Mibefradil is a potent inhibitor of T-type $\mathrm{Ca}^{2+}$ (Cav3.x) currents (Mishra and Hermsmeyer, 1994; Martin et al., 2000) and their involvement in long-term synaptic plasticity has been reported (Leresche and Lambert, 2017). Bath application of $10 \mu \mathrm{M}$ mibefradil did not cause any significant changes in basal synaptic transmission (m-EPSC, $-6.5 \pm 1.5 \%, \mathrm{n}=6$; Student's paired $t$ test, $\mathrm{p}=0.16$ and d-EPSC, $-15.3 \pm 8.8 \%, \mathrm{n}=6$; Student's paired $t$ test, $\mathrm{p}=0.17$; Fig. 6A,B) but prevented the induction of LTP by TBS $_{\text {hyp }}\left(\mathrm{V}_{\text {hold }}=-58.2 \pm 0.9 \mathrm{mV} ; \mathrm{n}=6\right.$; Table 1$)$. m-EPSC and d-EPSC amplitude changed by $-22.2 \pm 9.2 \%(\mathrm{n}=6$; Student's paired $t$ test, $\mathrm{p}=0.16)$ and $-4.4 \pm 10.0 \%(\mathrm{n}=6$; Student's paired $t$ test, $\mathrm{p}=0.47$; Fig. 6C,D), respectively. Moreover, TBS showed a weaker Golgi cell excitation compared to control $\left(\mathrm{V}_{\text {jump }}=3.9 \pm 0.3 \mathrm{mV}, \mathrm{n}=6\right.$; Student's unpaired $t$ test, $\left.\mathrm{p}=0.024\right)$ accompanied by a reduced action potential discharge $\left(\mathrm{f}_{\mathrm{TBS}}=8.3 \pm 5.06 \mathrm{~Hz}, \mathrm{n}=6\right.$; Student's unpaired $t$ test, $\mathrm{p}=0.035$; Fig. 6E).

We then evaluated the effect of the HVA $\mathrm{Ca}^{2+}$ channel blocker, nifedipine, on LTD. Nifedipine is a potent inhibitor of L-type $\mathrm{Ca}^{2+}$ (Cav1.x) currents (Nguemo et al., 2013; Striessnig et al., 2015) and their involvement in long-term synaptic plasticity has been reported (Leresche and Lambert, 2017). Bath application of $20 \mu \mathrm{M}$ nifedipine did not cause any significant changes in basal synaptic transmission (m-EPSC, $-0.1 \pm 4.1 \%, \mathrm{n}=5$; Student's paired $t$ test, $\mathrm{p}=0.7$ and d-EPSC, -16.8 $\pm 1.36 \%, \mathrm{n}=5$; Student's paired $t$ test, $\mathrm{p}=0.7$; Fig. $6 \mathrm{~A}, \mathrm{~B})$ but blocked the induction of LTD by $\mathrm{TBS}_{\text {dep }}\left(\mathrm{V}_{\text {hold }}=-43.5 \pm 1.1 \mathrm{mV} ; \mathrm{n}=5\right.$; Table 1$)$. $\mathrm{m}$-EPSC and d-EPSC amplitude changed by $-1.2 \pm$ $7.5 \%(\mathrm{n}=5$; Student's paired $t$ test, $\mathrm{p}=0.37)$ and $-6.5 \pm 9.9 \%(\mathrm{n}=5$; Student's paired $t$ test, $\mathrm{p}=0.42$; Fig. 6C, D), respectively. In addition, TBS showed a stronger Golgi cell excitation compared to control $\left(\mathrm{V}_{\text {jump }}=5.1 \pm 2.3 \mathrm{mV}, \mathrm{n}=5\right.$; Student's unpaired $t$ test, $\left.\mathrm{p}=0.05\right)$ whereas action potential discharge $\left(\mathrm{f}_{\mathrm{TBS}}=26.5 \pm 5.4 \mathrm{~Hz}, \mathrm{n}=5\right.$; Student's unpaired $t$ test, $\mathrm{p}=0.42$; Fig. 6E) was not significantly different. These results indicate that $\mathrm{T}$-type and L-type $\mathrm{Ca}^{2+}$ channel activation plays a 
fundamental and distinctive role in the voltage-dependent induction of long-term synaptic plasticity at excitatory Golgi cell synapses.

$* * *$ Fig. $6 * * *$

\section{Discussion}

This work reports for the first time long-term synaptic plasticity at excitatory synapses impinging on cerebellar Golgi cells in mice. This plasticity is bidirectional, with LTD and LTP being favored at depolarized and hyperpolarized potentials, respectively. Interestingly, this voltage-dependence of induction is inverted not just with respect to that of many other brain excitatory synapses (Lisman, 1989; Artola et al., 1990; Artola and Singer, 1993; Malenka and Bear, 2004; Feldman, 2009; Bliss et al., 2014) but also to that occurring at the neighboring granule cell synapses, which are conjointly activated with Golgi cells by mossy fibers in the cerebellar glomerulus (D'Errico et al., 2009). Thus the mossy fiber terminal can make different plasticity depending on its target cells. Correspondingly, the mechanisms of LTP and LTD induction involved differential engagement of voltage-gated $\mathrm{Ca}^{2+}$ channels rather than NMDA receptors alone (Volianskis et al., 2015). LTP and LTD generated by the granule cell ascending axon and parallel fibers were indistinguishable from that generated by mossy fibers, implying that mechanisms of induction reflected specific postsynaptic properties of the Golgi cell. It should be noted that, although the secondary multiple peaks in latency histograms were most likely related to distinct granule cell inputs to the basolateral and apical dendrites, it was not possible in these experiments to further dissect these components in terms of their induction properties.

\section{The mechanisms of inverted bidirectional plasticity}

The way Golgi cell plasticity is induced is in line with a set of observations about the membrane channel complement and the physiological activity of Golgi cells. Golgi cell dendrites are endowed with $\mathrm{Ca}^{2+}$ channels (Rudolph et al., 2015) and the excitatory synapses express NMDA receptors (Misra et al., 2000; Cesana et al., 2013). Accordingly, mossy fiber bursts caused synaptic calcium influx and dendritic calcium spikes in a voltage-dependent manner (see Fig. 3). It is therefore conceivable that modulation of Golgi cell membrane potential would profoundly affect calcium influx through these membrane channels thereby affecting the induction of long-term synaptic plasticity. We have actually tested the effect of T-type and L-type $\mathrm{Ca}^{2+}$ channels that are reported to play key roles in LTP and LTD induction (Leresche and Lambert, 2017). Neither T-type $\mathrm{Ca}^{2+}$ channel blockade (with mibefradil) nor L-type $\mathrm{Ca}^{2+}$ channel blockade (with nifedipine) 
significantly affected basal neurotransmission, suggesting that their action was primarily postsynaptic in our experiments. Actually, T-type $\mathrm{Ca}^{2+}$ channel activation (along with NMDA receptors) was required for LTP but not for LTD, while L-type channel activation was required for LTD. It should be noted that a recent work has reported a differential distribution of T-type and Rtype $\mathrm{Ca}^{2+}$ channels in distal dendrites and of L-type, N-type and P-type channels in basolateral dendrites (Rudolph et al., 2015). However, we did not find significant differences when considering monosynaptic and dysynaptic EPSCs. Subtle distinctive effects of these different $\mathrm{Ca}^{2+}$ channel subtypes on LTP and LTD induction remain to be investigated.

In addition to identify a correlation of membrane mechanisms with LTP or LTD, we observed that voltage changes during TBS were stronger from hyperpolarized than depolarized membrane potentials (measured with respect to the pacemaking potential of the cells). In aggregate, this set of observations can be explained by the following model. From slightly hyperpolarized potentials (about $-57 \mathrm{mV}$ ), at which T-type $\mathrm{Ca}^{2+}$ channels are de-inactivated, TBS would cause a strong Golgi cell excitation by virtue of T-type $\mathrm{Ca}^{2+}$ channel opening. This would generate a depolarizing hump (actually a calcium spike) unblocking the NMDA channels and raising intracellular calcium above LTP threshold. From slightly depolarized potentials (about $-41 \mathrm{mV}$ ), at which T-type $\mathrm{Ca}^{2+}$ channels are inactivated, TBS would cause weak Golgi cell excitation since the calcium spike would be prevented along with NMDA channel unblock. Nonetheless, enough calcium would still enter through L-type $\mathrm{Ca}^{2+}$ channels causing LTD. It is therefore possible that the intracellular calcium-dependent machinery respects the Lisman paradigm [low calcium for LTD, high calcium for LTP (Lisman, 1989; Shouval et al., 2002)] with a voltage-dependent induction mechanism enhancing calcium influx from hyperpolarized membrane potential. Similar (but probably not identical) LTP and LTD induction mechanisms engaging combinations of NMDA and voltage-gated T-type and L-type $\mathrm{Ca}^{2+}$ channels have also been reported at synapses in thalamic nuclei, deep cerebellar nuclei, cerebral cortex, hippocampus and striatum (Leresche and Lambert, 2017).

\section{Functional implications}

Since the depolarization and hyperpolarization used to induced plasticity were around the pacemaking potential of the Golgi cell (about $\pm 10 \mathrm{mV}$ ), it is possible that the induction mechanism is physiologically regulated by local network activity. The membrane potential change needed to switch between LTP and LTD can be driven by inhibitory and excitatory synaptic activity. While excitatory synapses are activated by mossy fibers as well as in granule cells through their ascending axons and parallel fibers (Cesana et al., 2013), inhibitory synapses are provided by neighboring 
Golgi cells (Hull and Regehr, 2012) and from Lugaro cells, while inputs from stellate and basket cells are still disputed (Dieudonne, 1998; Bureau et al., 2000; Misra et al., 2000). Moreover, neuromodulators could also bias Golgi cell membrane potential (Geurts et al., 2002; Schweighofer et al., 2004; Fleming and Hull, 2019). The activity of Golgi cells can also be influenced by the climbing fibers (Xu and Edgley, 2008) although the mechanisms is unclear and direct synaptic contacts have not been demonstrated (Galliano et al., 2013). There is therefore a rich set of mechanisms that could determine the direction of plastic changes at Golgi cell excitatory synapses.

This novel form of plasticity places the Golgi cells in a pivotal position to regulate information flow through the granular layer. Actually, strong mossy fiber bursts turn out to induce both LTP of glutamatergic excitation in granule cells (D'Errico et al., 2009), LTD of glutamatergic excitation in Golgi cells (this paper) and LTD of GABAergic inhibition between Golgi cells and granule cells (Mapelli et al., 2015). This would eventually cause a global long-term enhancement of granule cell excitation (both directly and indirectly through reduced Golgi cell-mediated inhibition) thereby enhancing transmission gain. The opposite would occur with poorly depolarizing inputs. Interestingly, hyperpolarization was also shown to induce a long-term increase in the spontaneous firing rate of cerebellar Golgi cells (Hull et al., 2013) and very strong impulse trains in the parallel fibers were reported to induce a form of LTD (Robberechts et al., 2010) suggesting that multiple long-term regulatory mechanisms coexist.

\section{Conclusions}

Long-term changes in Golgi cell synaptic transmission determined by patterned mossy fiber synaptic inputs and could have relevant implications for granular layer processing. The granular layer is thought to operate as an adaptive filter (Dean and Porrill, 2010) and modifying the inhibitory effect of Golgi cells through plasticity has been proposed as a key factor to regulate signal transformations at the cerebellum input stage. In a first hypothesis, plasticity was simply thought to weight Golgi cell inhibition of granule cells without specifying the synaptic process involved (Schweighofer et al., 2001). A more elaborated model implied the existence of LTP and LTD at the mossy fiber - Golgi cell synapses and anticipated their correlation with low-frequency oscillations of granular layer activity (Garrido et al., 2016). This work actually shows that Golgi cell plasticity is strictly bound to its electrophysiological properties and sets constraints to future models of the granular layer, that might allow to better understand the mechanisms of cerebellar learning and memory (Marr, 1969; Ito, 2008; Koziol et al., 2014; Sokolov et al., 2017; D'Angelo, 2019). 


\section{Legends}

\section{Figure 1. Golgi cells and their excitatory input.}

(A) Schematic of the afferent excitatory connections to a Golgi cell activated by mossy fiber stimulation. Golgi cell (GoC); mossy fiber (mf); granule cell (GrC); ascending axon (aa); parallel fiber (pf). The figure highlights the interactions of elements in the cerebellar glomerulus and the location of afferent Golgi cell synapses. (1) mf-Golgi cell monosynaptic connection; (2) mf-GrC-GoC disynaptic connection on aa; $(3,4)$ short and long mf-GrC-GoC disynaptic connection on pf. The inset shows an enlargement of the contacts within the cerebellar glomerulus.

(B) Fluorescence image of a Golgi cell filled with AlexaFluo-594 and recorded in whole-cell patch-clamp configuration (courtesy of Prof. Javier De Felipe).The trace on the right shows the typical Golgi cells autorhythmic firing $(4.0 \mathrm{~Hz})$ in the presence of $\mathrm{GABA}_{\mathrm{A}}$ and glycine receptor blockers.

(C) EPSC latency in four different Golgi cells. Latency histograms show a multimodal distribution, with a first narrow peak corresponding to monosynaptic activation that could be followed by 2-3 well distinguishable later peaks corresponding to disynaptic activation (cf. panel A). A multi Gaussian fitting (red traces) is superimposed and the nonlinear regression coefficient $\left(\mathrm{R}^{2}\right)$ are is indicated. Inset traces show the average of 30 EPSCs (scale bar $40 \mathrm{pA}$, $5 \mathrm{~ms})$.

Figure 2. Bidirectional plasticity at Golgi cell excitatory synapses: dependence on membrane potential

LTP or LTD were induced by delivering TBS from different Golgi cell membrane potentials. (A) Left, EPSCs (average of 30 tracings) recorded before and $30 \mathrm{~min}$ after the delivery of $\mathrm{TBS}_{\text {hyp }}$ (black traces) and $\mathrm{TBS}_{\text {dep }}$ (gray traces). Right, average time course of m-EPSC amplitude changes during LTP and LTD. The arrow indicates the induction time and each point is the average of 15 contiguous EPSC amplitudes. Data are reported as mean \pm SEM.

(B) The histogram shows the average m-EPSC and d-EPSC \% change following $\mathrm{TBS}_{\text {hyp }}$ (black) and $\mathrm{TBS}_{\mathrm{dep}}$ (gray). Data are reported as mean $\pm \mathrm{SEM},{ }^{*} \mathrm{p}<0.05$, ${ }^{*} \mathrm{p}<0.01$, Student's paired $t$ test.

(C) Golgi cell response during $\mathrm{TBS}_{\mathrm{hyp}}$ and $\mathrm{TBS}_{\mathrm{dep}}$. Note the stronger depolarization and spike generation in $\mathrm{TBS}_{\text {hyp }}$ than $\mathrm{TBS}_{\text {dep. }}$. The figure shows $\mathrm{V}_{\text {hold }}$ and $\mathrm{V}_{\text {jump }}$ in the two cases.

(D) The plot shows the relationship between membrane holding potential ( $\left.\mathrm{V}_{\text {hold }}\right)$ and m-EPSC amplitude and can be fitted with straight line (linear regression $R^{2}=0.57, n=13, p(F)=0.002$ ) 
(E) The 3D graph shows m-EPSC amplitude change as a function of the efficiency of Golgi cell synaptic excitation during $\mathrm{TBS}_{\mathrm{hyp}}$ and $\mathrm{TBS}_{\mathrm{dep}}$ evaluated as $\mathrm{V}_{\mathrm{jump}}$ and spike frequency .

\section{Figure 3. Postsynaptic Ca ${ }^{2+}$-dependent induction of LTP and LTD}

(A) Left, EPSCs (average of 30 tracings) recorded before and $30 \mathrm{~min}$ after the delivery of TBS $_{\text {hyp }}$ (black traces) and TBS $_{\text {dep }}$ (gray traces) with $10 \mathrm{mM}$ EGTA in the intracellular solution. Right, average time course of m-EPSC amplitude changes. The arrow indicates the induction time and each point is the average of 15 contiguous EPSC amplitudes. Note that high EGTA prevented both LTP and LTD. The black and gray lines are replotted from Fig. $2 \mathrm{~A}$ to compare LTP and LTD in control condition. Data are reported as mean \pm SEM.

(B) The histogram shows the average m-EPSC and d-EPSC \% change following $\mathrm{TBS}_{\text {hyp }}$ (black) and $\mathrm{TBS}_{\mathrm{dep}}$ (gray). Data are reported as mean $\pm \mathrm{SEM}$.

(C) The 3D graph shows m-EPSC amplitude change as a function of the efficiency of Golgi cell synaptic excitation during $\mathrm{TBS}_{\mathrm{hyp}}$ and $\mathrm{TBS}_{\mathrm{dep}}$ (evaluated both as $\mathrm{V}_{\text {jump }}$ and spike frequency) in the presence of high EGTA. The black and gray dotted areas are replotted from Fig. 2E to compare m-EPSC amplitude change as a function of the efficiency of Golgi cell synaptic excitation during $\mathrm{TBS}_{\mathrm{hyp}}$ and $\mathrm{TBS}_{\mathrm{dep}}$ in control.

\section{Figure 4. The relationship between $\left[\mathrm{Ca}^{2+}\right]_{i}$ changes and Golgi cell synaptic plasticity.}

(A) Left, $\mathrm{Ca}^{2+}$ transients elicited by $\mathrm{TBS}_{\text {hyp }}$ (black traces) and $\mathrm{TBS}_{\text {dep }}$ (gray traces). Inset, unprocessed fluorescence image of a Golgi cell filled with $200 \mu \mathrm{M}$ OG1. Scale bar, $10 \mu \mathrm{m}$. Fluorescence intensity is color coded with arbitrary units within an interval chosen to allow the visualization of the basolateral dendrites (note that, although the soma fluorescence appears saturated within this interval, it does not saturate the CCD detectors). Right, histograms show the $\left(\Delta \mathrm{F} / \mathrm{F}_{0}\right)_{\max }$ induced by $\mathrm{TBS}_{\text {hyp }}$ and $\mathrm{TBS}_{\mathrm{dep}}$, respectively. Data are reported as mean \pm SEM, $* * * \mathrm{p}<0.005$, Student's paired $t$ test.

(B) The time series of pseudoratio images from the same Golgi cell in A (warmer color code for higher $\left.\Delta \mathrm{F} / \mathrm{F}_{0}\right)$ is shown. $\Delta \mathrm{F} / \mathrm{F}_{0}$ is evaluated in the ROI.

(C) Left, EPSCs (average of 30 tracings) recorded before and $30 \mathrm{~min}$ after the delivery of $\mathrm{TBS}_{\text {hyp }}$ (black traces) and $\mathrm{TBS}_{\text {dep }}$ (gray traces) with $200 \mu \mathrm{M}$ BAPTA in the intracellular solution. Right, the average time course of m-EPSC amplitude changes. The arrow indicates the induction time and each point is the average of 15 contiguous EPSC amplitudes. LTD and LTP observed using $200 \mu \mathrm{M}$ BAPTA was indistinguishable from that observed in control 
condition (0.2 mM EGTA). The black and gray lines are replotted from Fig. 2A to compare LTP and LTD in control condition. Data are reported as mean \pm SEM.

(D) The histogram shows the average m-EPSC and d-EPSC \% change following $\mathrm{TBS}_{\mathrm{hyp}}$ and $\mathrm{TBS}_{\text {dep }}$. Data are reported as mean \pm SEM, *p $<0.05, * * \mathrm{p}<0.01, * * * \mathrm{p}<0.005$, Student's paired $t$ test.

(E) The 3D graph shows m-EPSC amplitude change as a function of the efficiency of Golgi cell synaptic excitation during $\mathrm{TBS}_{\mathrm{hyp}}$ and $\mathrm{TBS}_{\mathrm{dep}}$ (evaluated both as $\mathrm{V}_{\text {jump }}$ and spike frequency)

\section{Figure 5. NMDA receptor-dependent induction of LTP}

(A) Left, EPSCs (average of 30 tracings) recorded before and $10 \mathrm{~min}$ after the bath application of the NMDA receptor antagonist, D-APV $(50 \mu \mathrm{M})$. Right, the average time course of m-EPSC amplitude changes. The black bar indicates the duration of perfusion and each point is the average of 5 contiguous EPSC amplitudes. Note that D-APV did not cause changes in basal transmission.

(B) The histogram shows the average m-EPSC and d-EPSC \% change in the presence of DAPV. Data are reported as mean \pm SEM.

(C) Left, EPSCs (average of 30 tracings) recorded before and $30 \mathrm{~min}$ after the delivery of $\mathrm{TBS}_{\text {hyp }}$ (black traces) and $\mathrm{TBS}_{\text {dep }}$ (gray traces) with $50 \mu \mathrm{M}$ D-APV in the bath (black bar). Right, the average time course of m-EPSC amplitude changes. The arrow indicates the induction time and each point is the average of 15 contiguous EPSC amplitudes. Note that DAPV completely blocked the induction of LTP while the magnitude of LTD was not significantly different from that in the absence of NMDA receptor block. The black and gray lines are replotted from Fig. 2A to compare LTP and LTD in control condition. Data are reported as mean \pm SEM.

(D) The histogram shows the average m-EPSC and d-EPSC \% change following $\mathrm{TBS}_{\mathrm{hyp}}$ and $\mathrm{TBS}_{\mathrm{dep}}$ in the presence of D-APV. Data are reported as mean \pm SEM, ${ }^{*} \mathrm{p}<0.05$, Student's paired $t$ test.

(E) The 3D graph shows m-EPSC amplitude change as a function of the efficiency of Golgi cell synaptic excitation during $\mathrm{TBS}_{\mathrm{hyp}}$ and $\mathrm{TBS}_{\mathrm{dep}}$ (evaluated both as $\mathrm{V}_{\text {jump }}$ and spike frequency) in the presence of D-APV. The black and gray dotted areas are replotted from Fig. $2 \mathrm{E}$ to compare m-EPSC amplitude change as a function of the efficiency of Golgi cell synaptic excitation during $\mathrm{TBS}_{\mathrm{hyp}}$ and $\mathrm{TBS}_{\mathrm{dep}}$ in control condition. 


\section{Figure 6. Voltage-gated calcium channel -dependent induction of LTP and LTD}

(A) Left, EPSCs (average of 30 tracings) recorded before and $10 \mathrm{~min}$ after the bath application of the T-type and L-type $\mathrm{Ca}^{2+}$ channel blockers, $10 \mu \mathrm{M}$ mibefradil and $20 \mu \mathrm{M}$ nifedipine, respectively. Right, the average time course of m-EPSC amplitude changes. The black bar indicates the duration of perfusion and each point is the average of 5 contiguous EPSC amplitudes. Note that neither mibefradil or nifedipine produced any remarkable changes in basal transmission.

(B) The histogram shows the average m-EPSC and d-EPSC \% change in the presence of mibefradil and nifedipine. Data are reported as mean \pm SEM.

(C) Left, EPSCs (average of 30 tracings) recorded before and $30 \mathrm{~min}$ after the delivery of $\mathrm{TBS}_{\text {hyp }}$ (black traces) in the presence of $10 \mu \mathrm{M}$ mibefradil and $\mathrm{TBS}_{\text {dep }}$ (gray traces) in the presence of $20 \mu \mathrm{M}$ nifedipine in the bath (black bar). The arrow indicates the induction time and each point is the average of 15 contiguous EPSC amplitudes. Note that mibefradil blocked the induction of LTP while nifedipine blocked the induction of LTD. The black and gray lines were replotted from Fig. 2A to compare show LTP and LTD in control condition. Data are reported as mean \pm SEM.

(D) The histogram shows the average m-EPSC and d-EPSC \% change following $\mathrm{TBS}_{\text {hyp }}$ in the presence of mibefradil and $\mathrm{TBS}_{\mathrm{dep}}$ in the presence of nifedipine. Data are reported as mean \pm SEM.

(E) The 3D graph shows m-EPSC amplitude change as a function of the efficiency of Golgi cell synaptic excitation (evaluated both as $\mathrm{V}_{\text {jump }}$ and spike frequency) during $\mathrm{TBS}_{\mathrm{hyp}}$ in the presence of mibefradil and during $\mathrm{TBS}_{\mathrm{dep}}$ in the presence of nifedipine. The black and gray dotted areas are replotted from Fig. 2E to compare m-EPSC amplitude changes as a function of the efficiency of Golgi cell synaptic excitation during $\mathrm{TBS}_{\text {hyp }}$ and $\mathrm{TBS}_{\text {dep }}$ in control condition.

\section{References}

Andreescu CE, Prestori F, Brandalise F, D'Errico A, De Jeu MT, Rossi P, Botta L, Kohr G, Perin P, D'Angelo E, De Zeeuw $\mathrm{Cl}$ (2011) NR2A subunit of the $\mathrm{N}$-methyl d-aspartate receptors are required for potentiation at the mossy fiber to granule cell synapse and vestibulo-cerebellar motor learning. In: Neuroscience, pp 274-283. United States: 2011 IBRO. Published by Elsevier Ltd.

Armano S, Rossi P, Taglietti V, D'Angelo E (2000) Long-term potentiation of intrinsic excitability at the mossy fiber-granule cell synapse of rat cerebellum. J Neurosci 20:5208-5216.

Artola A, Singer W (1993) Long-term depression of excitatory synaptic transmission and its relationship to long-term potentiation. Trends Neurosci 16:480-487.

Artola A, Bröcher S, Singer W (1990) Different voltage-dependent thresholds for inducing long-term depression and long-term potentiation in slices of rat visual cortex. Nature 347:69-72.

Billings G, Piasini E, Lorincz A, Nusser Z, Silver RA (2014) Network structure within the cerebellar input layer enables lossless sparse encoding. Neuron 83:960-974. 
Bliss TVP, Collingridge GL, Morris RGM (2014) Synaptic plasticity in health and disease: introduction and overview. In: Philos Trans R Soc Lond B Biol Sci.

Bureau I, Dieudonne S, Coussen F, Mulle C (2000) Kainate receptor-mediated synaptic currents in cerebellar Golgi cells are not shaped by diffusion of glutamate. Proc Natl Acad Sci U S A 97:6838-6843.

Cesana E, Pietrajtis K, Bidoret C, Isope P, D'Angelo E, Dieudonné S, Forti L (2013) Granule cell ascending axon excitatory synapses onto Golgi cells implement a potent feedback circuit in the cerebellar granular layer. J Neurosci 33:12430-12446.

D'Angelo E (2008) The critical role of Golgi cells in regulating spatio-temporal integration and plasticity at the cerebellum input stage. Front Neurosci 2:35-46.

D'Angelo E (2014) The organization of plasticity in the cerebellar cortex: from synapses to control. Prog Brain Res 210:31-58.

D'Angelo E (2019) The cerebellum gets social. Science 363:229.

D'Angelo E, De Zeeuw $\mathrm{Cl}$ (2009) Timing and plasticity in the cerebellum: focus on the granular layer. Trends Neurosci 32:30-40.

D'Angelo E, Rossi P, Armano S, Taglietti V (1999) Evidence for NMDA and mGlu receptor-dependent longterm potentiation of mossy fiber-granule cell transmission in rat cerebellum. J Neurophysiol 81:277-287.

D'Angelo E, Solinas S, Mapelli J, Gandolfi D, Mapelli L, Prestori F (2013) The cerebellar Golgi cell and spatiotemporal organization of granular layer activity. Front Neural Circuits 7:93.

D'Angelo E, Mapelli L, Casellato C, Garrido JA, Luque N, Monaco J, Prestori F, Pedrocchi A, Ros E (2016) Distributed Circuit Plasticity: New Clues for the Cerebellar Mechanisms of Learning. Cerebellum 15:139-151.

D'Errico A, Prestori F, D'Angelo E (2009) Differential induction of bidirectional long-term changes in neurotransmitter release by frequency-coded patterns at the cerebellar input. J Physiol 587:58435857.

Dean P, Porrill J (2010) The cerebellum as an adaptive filter: a general model? Funct Neurol 25:173-180.

Dieudonne $S$ (1998) Submillisecond kinetics and low efficacy of parallel fibre-Golgi cell synaptic currents in the rat cerebellum. J Physiol 510 ( Pt 3):845-866.

Dugué GP, Dumoulin A, Triller A, Dieudonné S (2005) Target-dependent use of co-released inhibitory transmitters at central synapses. J Neurosci 25:6490-6498.

Dumoulin A, Triller A, Dieudonne S (2001) IPSC kinetics at identified GABAergic and mixed GABAergic and glycinergic synapses onto cerebellar Golgi cells. J Neurosci 21:6045-6057.

Feldman DE (2009) Synaptic mechanisms for plasticity in neocortex. Annu Rev Neurosci 32:33-55.

Fleming E, Hull C (2019) Serotonin regulates dynamics of cerebellar granule cell activity by modulating tonic inhibition. J Neurophysiol 121:105-114.

Forti L, Cesana E, Mapelli J, D'Angelo E (2006) Ionic mechanisms of autorhythmic firing in rat cerebellar Golgi cells. J Physiol 574:711-729.

Gall D, Prestori F, Sola E, D'Errico A, Roussel C, Forti L, Rossi P, D'Angelo E (2005) Intracellular calcium regulation by burst discharge determines bidirectional long-term synaptic plasticity at the cerebellum input stage. J Neurosci 25:4813-4822.

Galliano E, Baratella M, Sgritta M, Ruigrok TJH, Haasdijk ED, Hoebeek FE, D'Angelo E, Jaarsma D, De Zeeuw $\mathrm{Cl}$ (2013) Anatomical investigation of potential contacts between climbing fibers and cerebellar Golgi cells in the mouse. Front Neural Circuits 7.

Gao Z, van Beugen BJ, De Zeeuw Cl (2012) Distributed synergistic plasticity and cerebellar learning. Nat Rev Neurosci 13:619-635.

Garrido JA, Ros E, D'Angelo E (2013) Spike timing regulation on the millisecond scale by distributed synaptic plasticity at the cerebellum input stage: a simulation study. Front Comput Neurosci 7:64.

Garrido JA, Luque NR, Tolu S, D'Angelo E (2016) Oscillation-Driven Spike-Timing Dependent Plasticity Allows Multiple Overlapping Pattern Recognition in Inhibitory Interneuron Networks. Int J Neural Syst 26:1650020.

Geurts FJ, De Schutter E, Timmermans JP (2002) Localization of 5-HT2A, 5-HT3, 5-HT5A and 5-HT7 receptorlike immunoreactivity in the rat cerebellum. J Chem Neuroanat 24:65-74. 
Hansel C, Linden DJ, D'Angelo E (2001) Beyond parallel fiber LTD: the diversity of synaptic and non-synaptic plasticity in the cerebellum. Nat Neurosci 4:467-475.

Hull C, Regehr WG (2012) Identification of an inhibitory circuit that regulates cerebellar Golgi cell activity. Neuron 73:149-158.

Hull CA, Chu Y, Thanawala M, Regehr WG (2013) Hyperpolarization Induces a Long-Term Increase in the Spontaneous Firing Rate of Cerebellar Golgi Cells. In: J Neurosci, pp 5895-5902.

Ito M (2008) Control of mental activities by internal models in the cerebellum. Nat Rev Neurosci 9:304-313.

Kanichay RT, Silver RA (2008) Synaptic and cellular properties of the feedforward inhibitory circuit within the input layer of the cerebellar cortex. J Neurosci 28:8955-8967.

Koziol LF, Budding D, Andreasen N, D'Arrigo S, Bulgheroni S, Imamizu H, Ito M, Manto M, Marvel C, Parker K, Pezzulo G, Ramnani N, Riva D, Schmahmann J, Vandervert L, Yamazaki T (2014) Consensus Paper: The Cerebellum's Role in Movement and Cognition. Cerebellum 13:151-177.

Leresche N, Lambert RC (2017) T-type calcium channels in synaptic plasticity. Channels (Austin) 11:121-139.

Lisman J (1989) A mechanism for the Hebb and the anti-Hebb processes underlying learning and memory. Proc Natl Acad Sci U S A 86:9574-9578.

Malenka RC, Bear MF (2004) LTP and LTD: an embarrassment of riches. Neuron 44:5-21.

Mapelli L, Pagani M, Garrido JA, D'Angelo E (2015) Integrated plasticity at inhibitory and excitatory synapses in the cerebellar circuit. Front Cell Neurosci 9:169.

Marr D (1969) A theory of cerebellar cortex. J Physiol 202:437-470.

Martin RL, Lee JH, Cribbs LL, Perez-Reyes E, Hanck DA (2000) Mibefradil block of cloned T-type calcium channels. J Pharmacol Exp Ther 295:302-308.

Medina JF, Mauk MD (2000) Computer simulation of cerebellar information processing. Nat Neurosci 3 Suppl:1205-1211.

Mishra SK, Hermsmeyer K (1994) Selective inhibition of T-type Ca2+ channels by Ro 40-5967. Circ Res 75:144-148.

Misra C, Brickley SG, Farrant M, Cull-Candy SG (2000) Identification of subunits contributing to synaptic and extrasynaptic NMDA receptors in Golgi cells of the rat cerebellum. J Physiol 524 Pt 1:147-162.

Mitchell SJ, Silver RA (2003) Shunting inhibition modulates neuronal gain during synaptic excitation. Neuron 38:433-445.

Moscato L, Montagna I, De Propris L, Tritto S, Mapelli L, D'Angelo E (2019) Long-Lasting Response Changes in Deep Cerebellar Nuclei in vivo Correlate With Low-Frequency Oscillations. Front Cell Neurosci 13:84.

Nguemo F, Fleischmann BK, Gupta MK, Saric T, Malan D, Liang H, Pfannkuche K, Bloch W, Schunkert H, Hescheler J, Reppel M (2013) The L-type Ca2+ channels blocker nifedipine represses mesodermal fate determination in murine embryonic stem cells. PLoS One 8:e53407.

Palay SC-P, V (1974) Cerebellar cortex: New York: Springer.

Pugh JR, Raman IM (2009) Nothing can be coincidence: synaptic inhibition and plasticity in the cerebellar nuclei. Trends Neurosci 32:170-177.

Robberechts Q, Wijnants M, Giugliano M, De Schutter E (2010) Long-term depression at parallel fiber to Golgi cell synapses. J Neurophysiol 104:3413-3423.

Rudolph S, Hull C, Regehr WG (2015) Active Dendrites and Differential Distribution of Calcium Channels Enable Functional Compartmentalization of Golgi Cells. J Neurosci 35:15492-15504.

Schweighofer N, Doya K, Lay F (2001) Unsupervised learning of granule cell sparse codes enhances cerebellar adaptive control. In: Neuroscience, pp 35-50. United States.

Schweighofer N, Doya K, Kuroda S (2004) Cerebellar aminergic neuromodulation: towards a functional understanding. Brain Res Brain Res Rev 44:103-116.

Sgritta M, Locatelli F, Soda T, Prestori F, D'Angelo EU (2017) Hebbian Spike-Timing Dependent Plasticity at the Cerebellar Input Stage. J Neurosci 37:2809-2823.

Shouval HZ, Bear MF, Cooper LN (2002) A unified model of NMDA receptor-dependent bidirectional synaptic plasticity. Proc Natl Acad Sci U S A 99:10831-10836.

Simat M, Parpan F, Fritschy JM (2007) Heterogeneity of glycinergic and gabaergic interneurons in the granule cell layer of mouse cerebellum. J Comp Neurol 500:71-83. 
Sokolov AA, Miall RC, Ivry RB (2017) The Cerebellum: Adaptive Prediction for Movement and Cognition. Trends Cogn Sci 21:313-332.

Solinas S, Forti L, Cesana E, Mapelli J, De Schutter E, D'Angelo E (2007) Fast-reset of pacemaking and thetafrequency resonance patterns in cerebellar golgi cells: simulations of their impact in vivo. Front Cell Neurosci 1:4.

Striessnig J, Ortner NJ, Pinggera A (2015) Pharmacology of L-type Calcium Channels: Novel Drugs for Old Targets? In: Curr Mol Pharmacol, pp 110-122.

Volianskis A, France G, Jensen MS, Bortolotto ZA, Jane DE, Collingridge GL (2015) Long-term potentiation and the role of N-methyl-D-aspartate receptors. Brain Res 1621:5-16.

Watanabe D, Inokawa H, Hashimoto K, Suzuki N, Kano M, Shigemoto R, Hirano T, Toyama K, Kaneko S, Yokoi M, Moriyoshi K, Suzuki M, Kobayashi K, Nagatsu T, Kreitman RJ, Pastan I, Nakanishi S (1998) Ablation of cerebellar Golgi cells disrupts synaptic integration involving GABA inhibition and NMDA receptor activation in motor coordination. Cell 95:17-27.

Xu W, Edgley SA (2008) Climbing fibre-dependent changes in Golgi cell responses to peripheral stimulation. J Physiol 586:4951-4959.

Zeilhofer HU, Studler B, Arabadzisz D, Schweizer C, Ahmadi S, Layh B, Bösl MR, Fritschy JM (2005) Glycinergic neurons expressing enhanced green fluorescent protein in bacterial artificial chromosome transgenic mice. J Comp Neurol 482:123-141.

Zhang W, Linden DJ (2006) Long-term depression at the mossy fiber-deep cerebellar nucleus synapse. J Neurosci 26:6935-6944. 
A

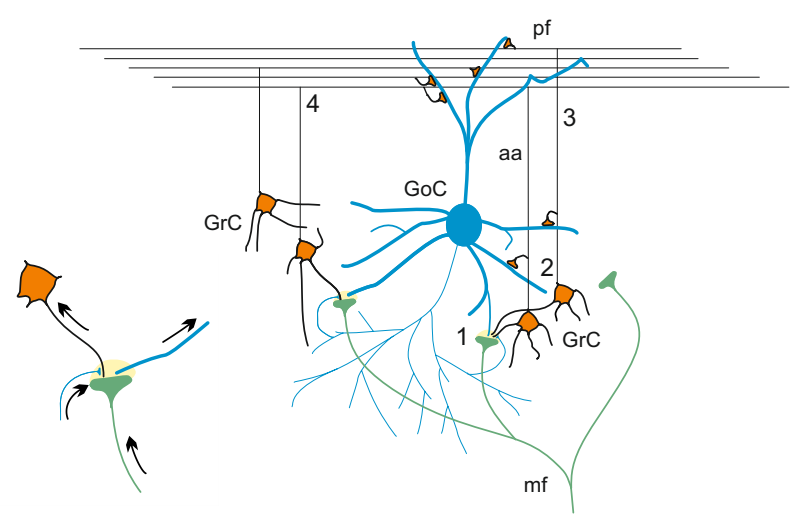

B

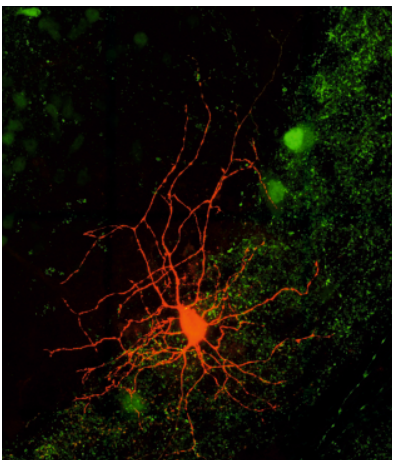

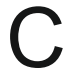
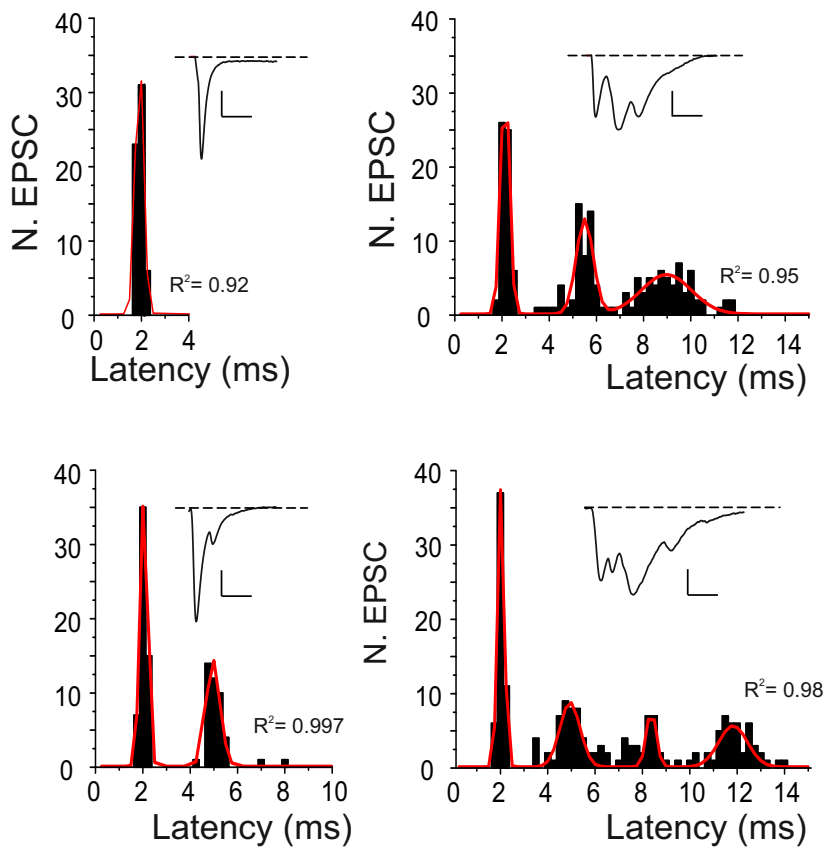

Figure 1 

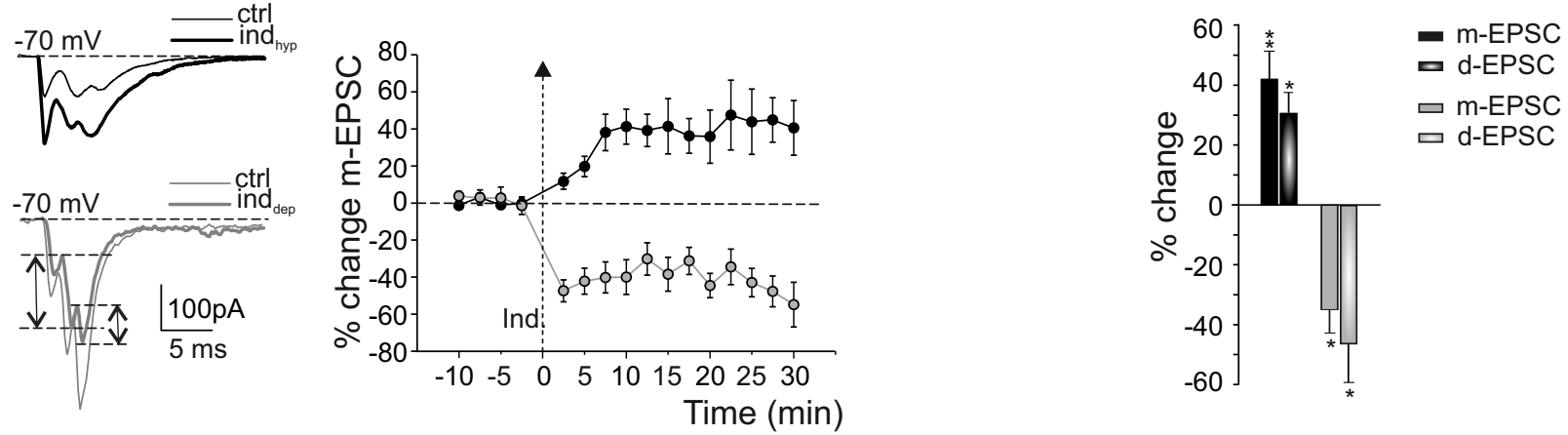

0

TBS - ind hyp

TBS - ind
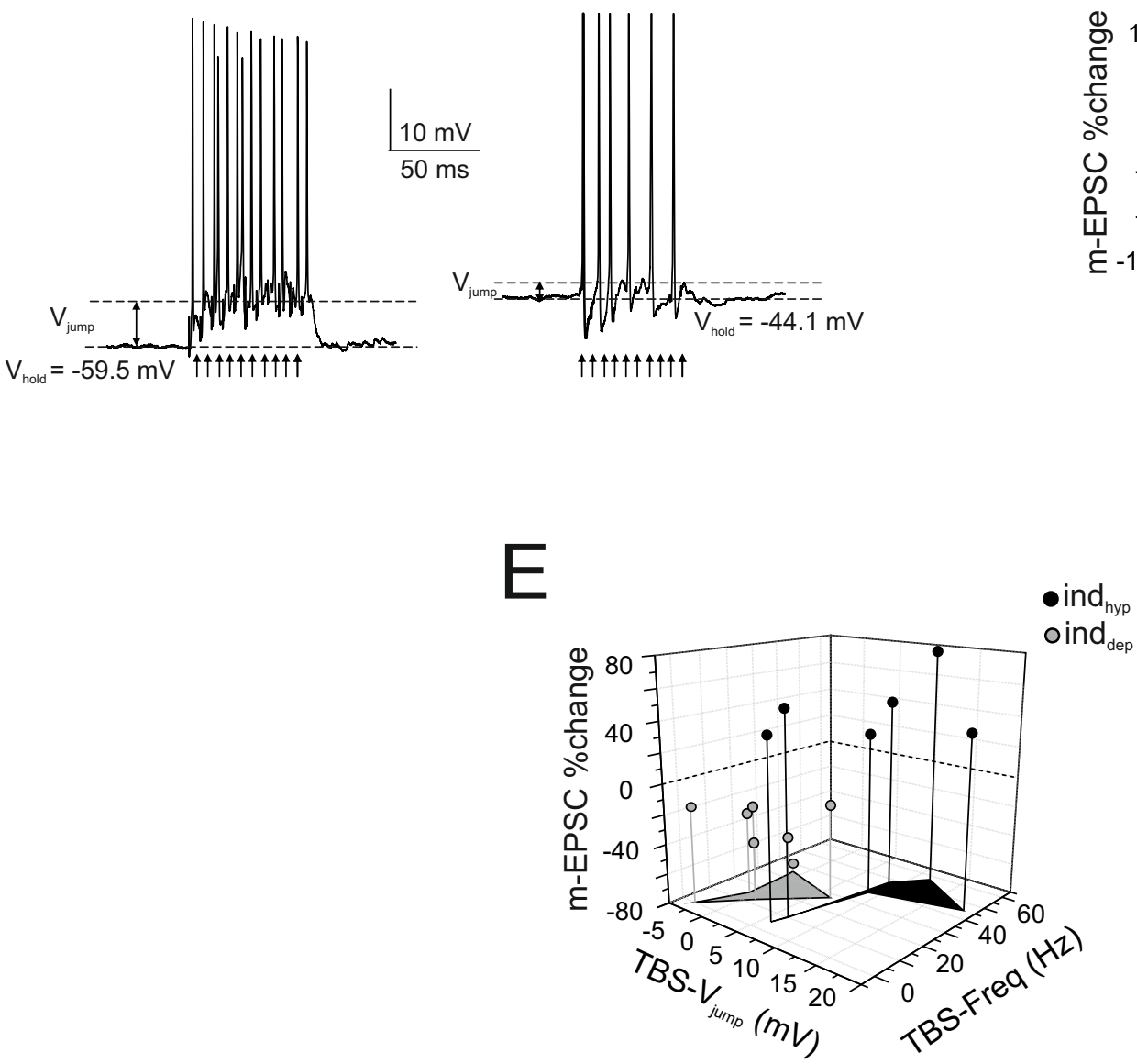

Figure 2

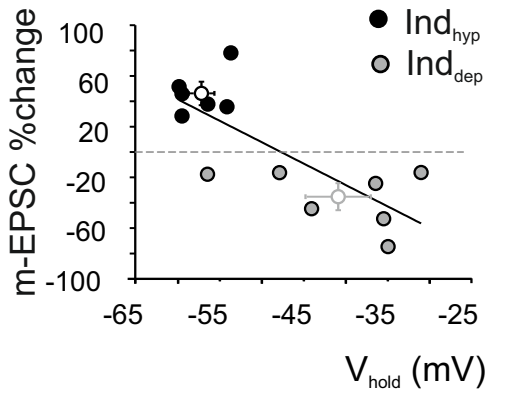

ind

oind $_{\text {dep }}$ 

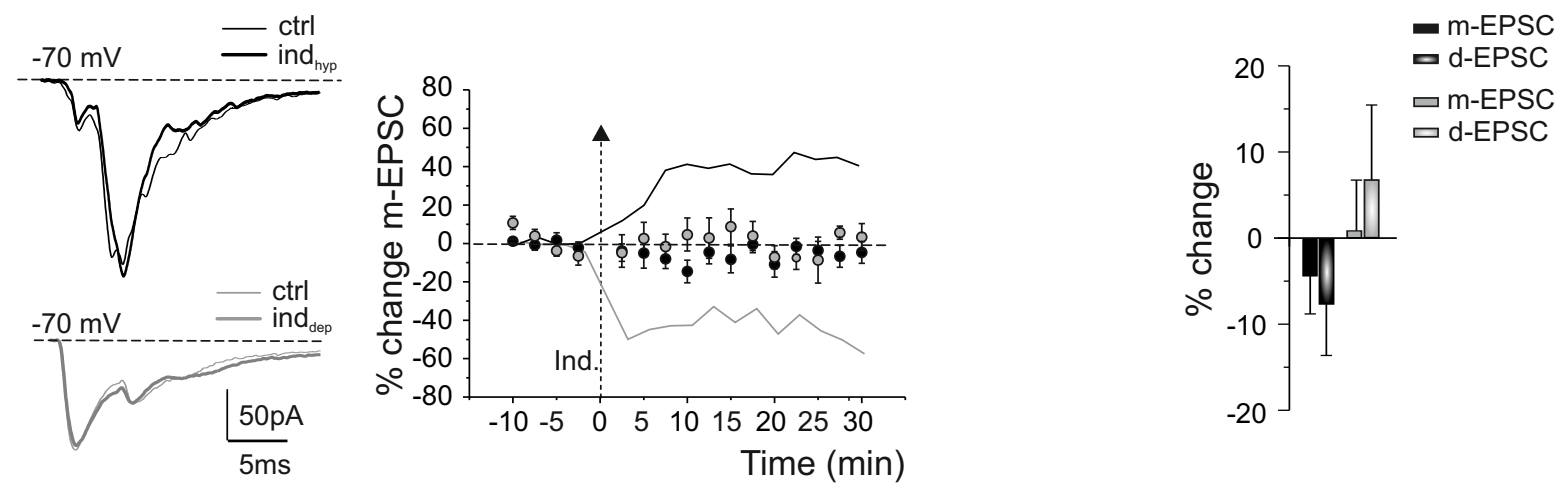

C

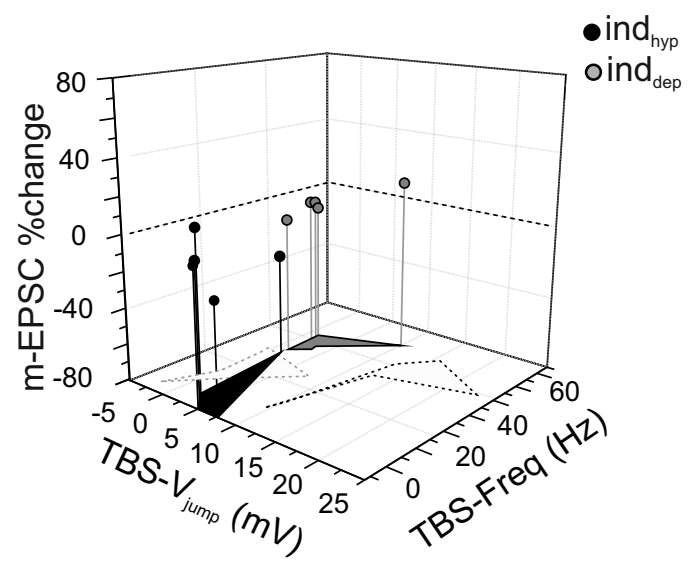

Figure 3 
A
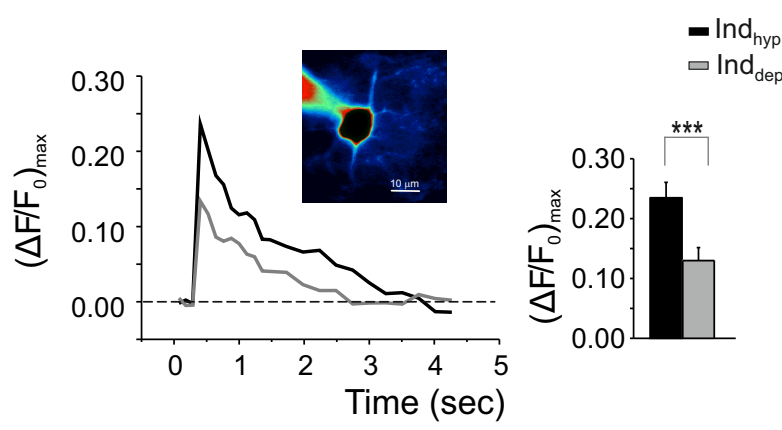

C
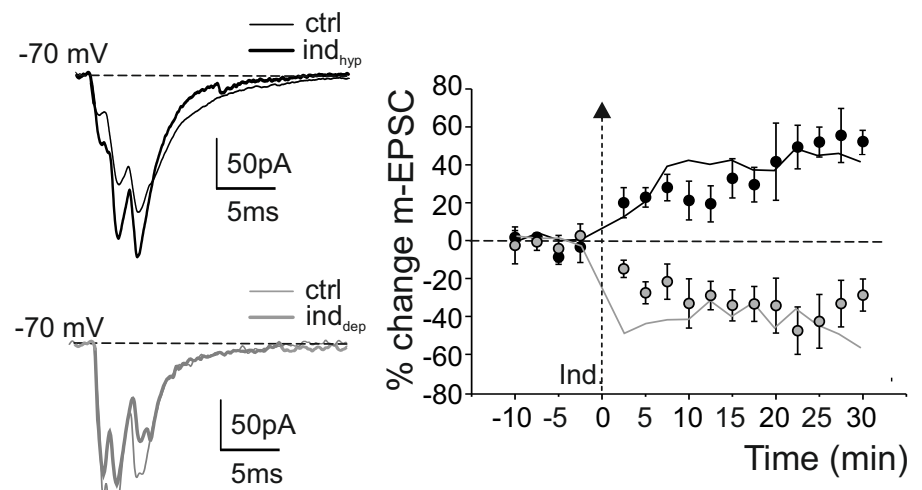

Ind $_{\text {dep }}$

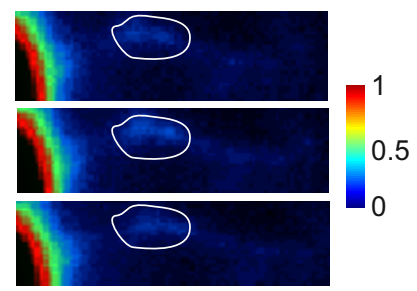

D
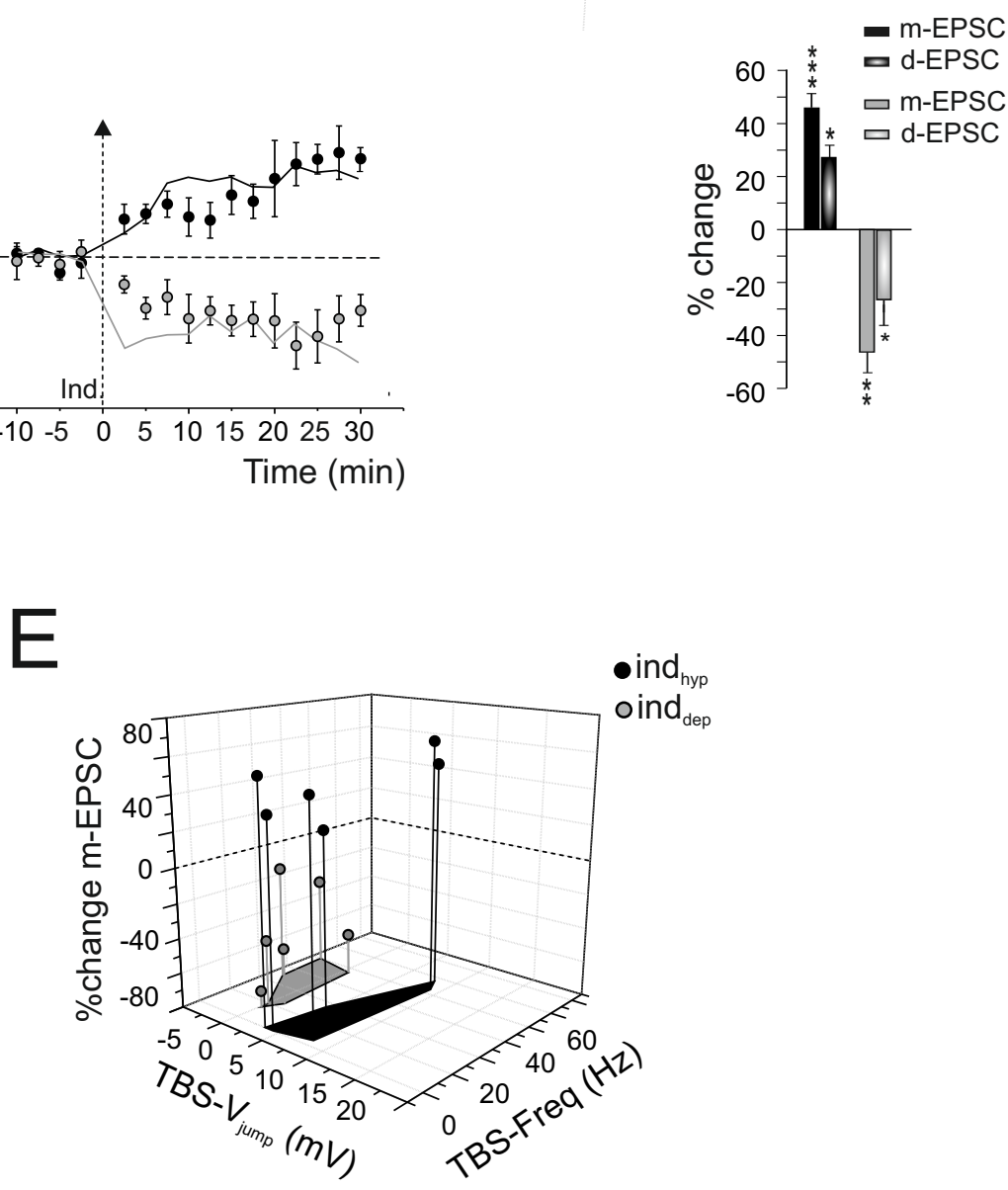

Figure 4 


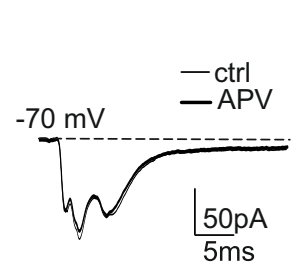

C

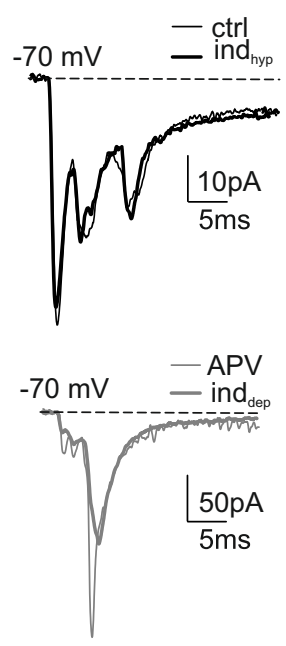

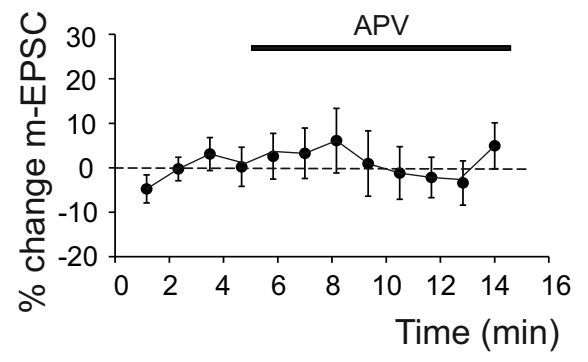

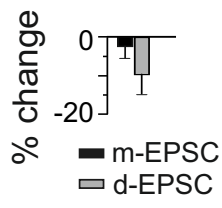

D
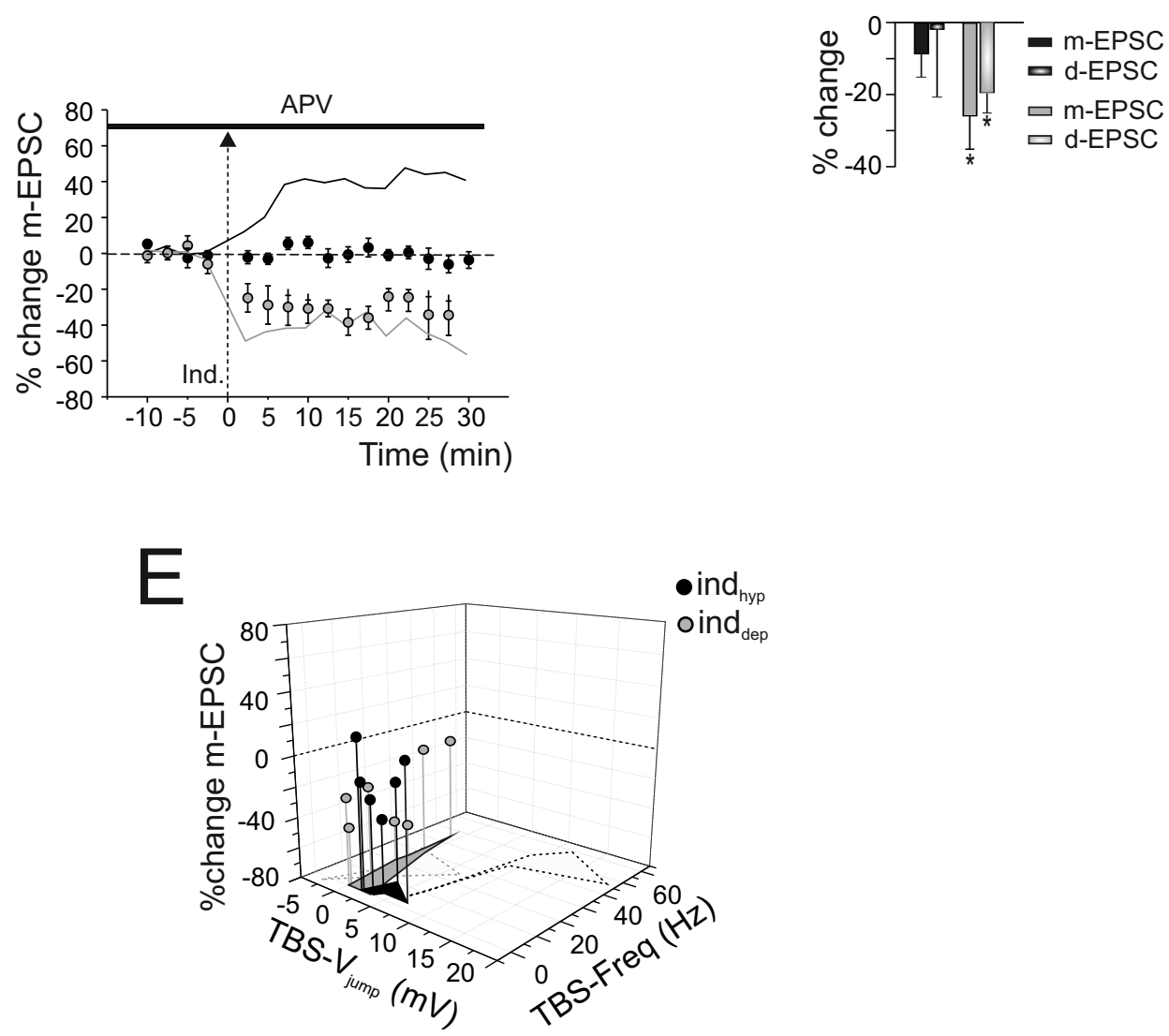

Figure 5 


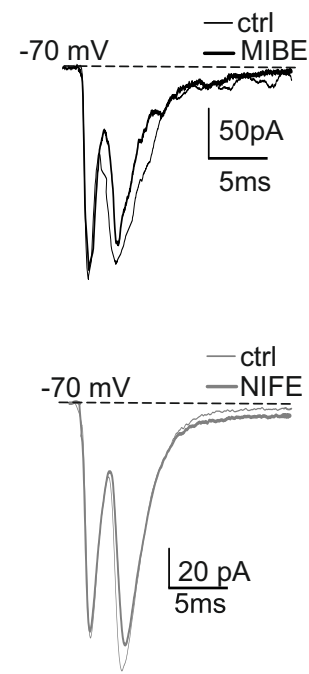

C

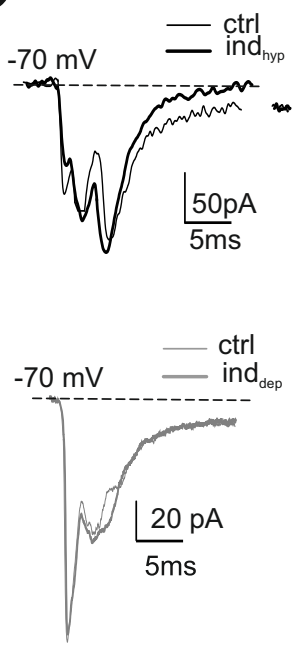

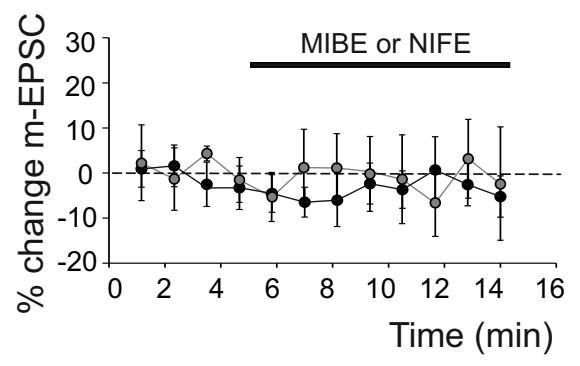

m-EPSC $\square \mathrm{m}$-EPSC
$\square \mathrm{d}-\mathrm{EPSC} \sim \mathrm{d}-\mathrm{EPSC}$

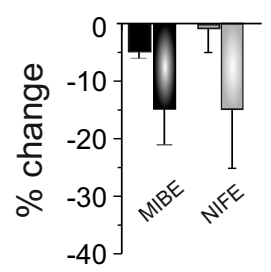

D
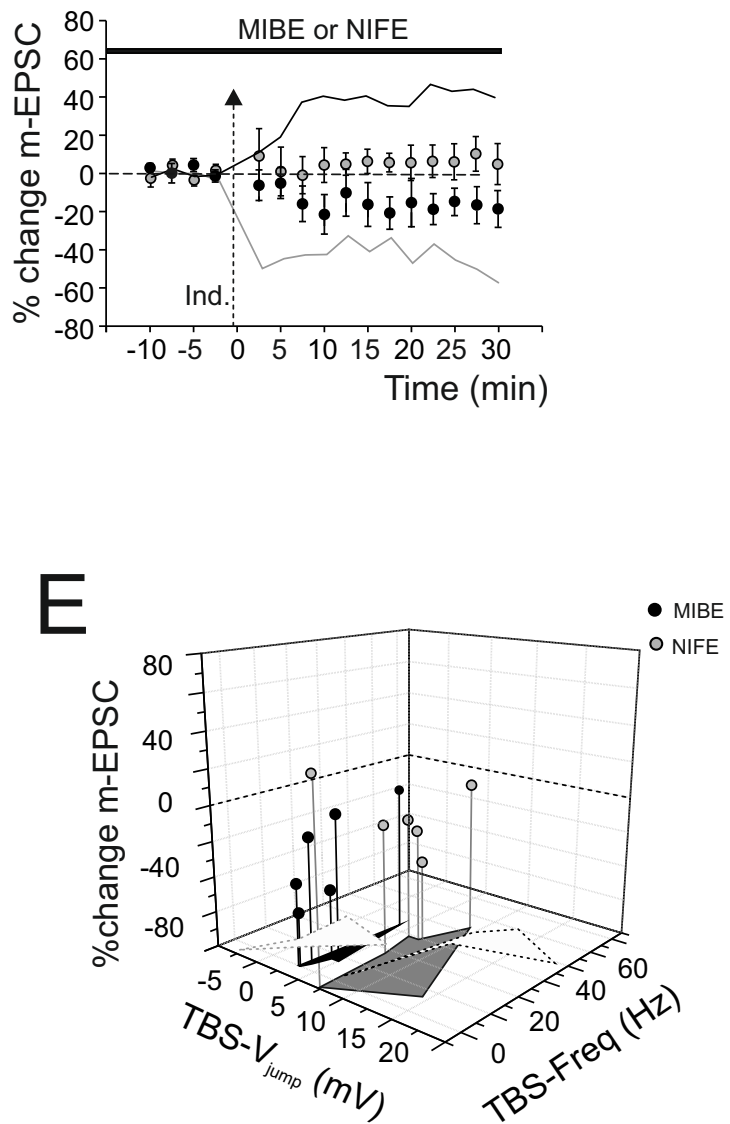

Figure 6 